\title{
RAFAE EYSYMONTT
}

Instytut Historii Sztuki Uniwersytetu Wrocławskiego

\section{SYMBOLIKA RATUSZY W PRZESTRZENI \\ MIASTA ŚREDNIOWIECZNEGO. WYBRANE PRZYKEADY}

\section{Uwagi wstępne}

Spośród wszystkich budowli miejskich to właśnie ratusz stanowi do czasów współczesnych najbardziej widoczny wynik ekonomicznych, kulturalnych i politycznych możliwości miasta oraz społecznych układów wspólnoty, jej potrzeb i jej regulacji prawnych ${ }^{1}$. Jest tak niezależnie od czasu powstania i skali budowli - niewielkiej, jak w Amöneburgu w Hesji, nieprzewyższajacej skalą szachulcowej zabudowy mieszkalnej miasta, czy na cykladzkiej wyspie Serifos, gdzie ratusz wyróżnia się spośród białych domów jedynie lekko ciemniejszą barwa, lub takiej jak w Wiedniu, gdzie dziewiętnastowieczna budowla konkuruje wyraźnie z innymi historycznymi monumentalnymi budowlami miasta - zamkiem i katedra. Istota jednak tego fenomenu ukształtowana została w zasadniczym stopniu w okresie średniowiecza, choć nie byłoby to możliwe bez wcześniejszej tradycji antycznej.

Trwanie tradycji antycznej w okresie średniowiecza w układach urbanistycznych jest tematem często poruszanym w dotychczasowej literaturze. Dotyczyła ona jednak głównie związków średniowiecznych miast lokacyjnych z rzymskim castrum, a także filozoficznych i religijnych podstaw idei estetycznych średniowiecznego miasta. Szczególnie ważne dla tego tematu wydaja się prace Haralda Kellera i Milosa Krumla ${ }^{2}$. Dla polskiej refleksji na ten temat istotne sa publikacje

\footnotetext{
${ }^{1}$ Spostrzeżenie takie pojawia się w: R. Eysymontt, Dawne ratusze we wspótczesnej Europie, w: Rada Miejska przez wieki. Materiały z konferencji, Wrocław 2008, s. 83-95.

${ }^{2}$ H. Keller, Die ostdeutsche Kolonialstadt des 13. Jahrhunderts und ihre südländischen Vorbilder, Wiesbaden 1979; M. Kruml, Die mittelalterliche Stadt als Gesamtkunswerk und Denkmal, Wien 1992.
} 
Tadeusza Zagrodzkiego ${ }^{3}$. Wszyscy ci autorzy widzą bezpośredni lub pośredni związek między ortogonalnym planem miasta średniowiecznego a tradycja antyczna, w tym tradycją rzymskich agrimensorów. O średniowiecznej matematyce i geometrii pisano już zreszta zdecydowanie wcześniej ${ }^{4}$. Najbardziej oczywistym pokłosiem antycznej tradycji były najstarsze średniowieczne lokacje z Półwyspu Apenińskiego. Enrico Guidoni w trzynastowiecznych miastach Półwyspu Apenińskiego dostrzegał wpływ doświadczeń późnoantycznych i wczesnośredniowiecznych gromatyków (matematyków i geometrów) ${ }^{5}$. Niektórzy z nich, jak Leonardo Pisano, mogliby mieć dla trzynastowiecznej tradycji włoskiej szczególne znaczenie ${ }^{6}$.

Wydaje się jednak, że antyczna tradycja wpływała nie tylko na kształt średniowiecznego założenia jako całości, warunkowała ona również lokalizację najważniejszych elementów funkcjonalno-przestrzennych, do których należał między innymi dom kupiecki i ratusz. Usytuowanie poszczególnych znaczących elementów pejzażu miasta średniowiecznego powinno być rozpatrzone w podobnie wnikliwy sposób, jak uczyniono to w wypadku placów, bloków zabudowy i parceli ${ }^{7}$. Dla głównych budowli komunalnych średniowiecznego miasta

${ }^{3}$ T. Zagrodzki dostrzegał niezwykle ważną dla średniowiecza antyczną tradycję matematyczna, zob. tenże, L’influence de la tradition antique de la distribution de l'étendue sur le tracé des plans des villes créées au Moyen Âge, w: Mélanges offerts à René Crozet à l'occasion de son 70e anniversaire par ses amis, ses collègues, ses élèves et le membres du C.E.S.C.M..., red. P. Gallais i Y.-J. Riou, Poitiers 1966, s. 453. Najważniejsza polskojęzyczna praca Zagrodzkiego na ten temat dotyczy Torunia: tenże, Ze studiów nad tradycjami rzymskiej limitacji mierniczej $w$ średniowieczu. Plan Starego Miasta $w$ Toruniu, „Zapiski Historyczne” 40, 1975, nr 1, s. 9-32.

${ }^{4}$ S. Günther, Geschichte des mathematischen Unterrichts im Deutschen Mittelalter bis zum Jahre 1525, Berlin 1887, s. 326-328.

${ }^{5}$ E. Guidoni, Storia dell'urbanistica. Il Duecento, Bari 1989, s. 241, 282 i n.

${ }^{6}$ Scritti di Leonardo Pisano, matematico, pubblicati da Baldassare Boncompagni, t. 2, Roma 1862.

${ }^{7}$ Kluczowy dla tego zagadnienia wydaje się tekst Heinricha Strahma, Die Area in der Städten, „Schweizer Beiträge zur Allgemeinen Geschichte” 3, 1945, s. 22-61. Z polskiej literatury najwcześniejsze i kluczowe dla tej kwestii wydają się prace Janusza Pudełki: Próba pomiarowej metody badania planów niektórych miast średniowiecznych w oparciu o zagadnienie dziatki, „Kwartalnik Architektury i Urbanistyki” (dalej: KAU) 9, 1964, nr 1, s. 3-26; tenże, Działka lokacyjna w strukturze przestrzennej średniowiecznych miast ślaskich $w$ XIII w., KAU 9, 1964, nr 2, s. 115-136. Metoda ta rozwijana jest ostatnio przez Bogusława Krasnowolskiego i Małgorzatę Chorowska, zob. B. Krasnowolski, Lokacyjne uktady urbanistyczne na obszarze Ziemi Krakowskiej w XIII i XIV wieku, cz. 1: Miasta Ziemi Krakowskiej, chronologia procesów osadniczych i typologia układów urbanistycznych, cz. 2: Katalog układów urbanistycznych, Kraków 2004; M. Chorowska, Metodologia badań średniowiecznego miasta na przyktadzie 
zdecydowanie ważniejsze wydaje się jednak „trójwymiarowe” widzenie średniowiecznego miasta jako całości ${ }^{8}$. Wieża ratuszowa jest jednym z zasadniczych składników korony pejzażu miejskiego. Pisali już o tym Mieczysław Zlat i Teresa Zarębska ${ }^{9}$. Niniejsze studium jest szkicem innych niż przez nich poruszane przykładów ważnych dla tego zagadnienia. Maja one zilustrować kilka istotnych aspektów symbolicznej funkcji ratusza $\mathrm{w}$ przestrzeni miejskiej, zarówno na obszarze miast o antycznych korzeniach, jak i miast jedynie pośrednio z taka tradycja związanych.

\section{Ratusz na obszarze niemieckim ${ }^{10}$}

Najstarszy ratusz na obszarze niemieckim to pochodzący z $1120 \mathrm{r}$. Domus Consulum w Soest (niektórzy wymieniaja jednak jako czas jego powstania datę o 100 lat późniejsza); w 1149 r. powstał domus civium w Kolonii. Trzeba przypomnieć, że pierwotnie celom zgromadzenia miejskiego służył również kościół. Osobna grupa obiektów to domy wójtowskie i sołtysie - wznoszone jako budowle salowe lub wieże mieszkalne. W Gelnhausen pochodzący z około 1180-1200 r. dwukondygnacyjny romański dom po południowej stronie rynku zwany był pretorium, w 1247 r. powstał dom wójtowski we Fritzlar,

\footnotetext{
Świdnicy. Kamienica, parcela, plan, w: Poznávání a dokumentace historických staveb. Sborník př́spěvků ze 4. konference SHP ze 4 konference stavebněhistorického průzkumu, Poděbrady, 31. května. - 3. června 2005., Praha 2006, s. 137-149. O rozplanowaniu geometrycznym miasta śląskiego jako całości pisał Tadeusz Kozaczewski: Wielkość i program budowy miasta średniowiecznego, Wrocław 1972 (Prace naukowe Instytutu Historii Architektury, Sztuki i Techniki Politechniki Wrocławskiej. Monografie, 3); tenże, Rozplanowanie, układ przestrzenny i rozwój miasta średniowiecznego, Wrocław 1973 (Prace naukowe Instytutu Historii Architektury, Sztuki i Techniki Politechniki Wrocławskiej. Monografie, 4).

8 Takie widzenie generuje możliwość rozpatrzenia miasta średniowiecznego jako wyniku świadomego wyznaczenia osi urbanistycznych między jego zasadniczymi elementami funkcjonalnymi. R. Eysymontt, Kod genetyczny miasta. Średniowieczne miasta lokacyjne Dolnego Ślaska na tle urbanistyki europejskiej, Wrocław 2009, s. 74-89.

${ }^{9}$ M. Zlat, Ratusz - zamek mieszczan: symbolika typu architektonicznego $i$ jego form, w: Ratusz w miastach pótnocnej Europy. Materiaty z sesji „Ratusz w miastach nadbattyckich", Gdańsk 23-25 XI 1993, red. S. Latour, Gdańsk 1997, s. 13-36; T. Zarębska, Kontekst urbanistyczny ratusza Gtównego Miasta w Gdańsku, w: tamże, s. 53-77; R. Eysymontt, Kod..., s. 76-81.

${ }^{10}$ Informacje w tym rozdziale głównie na podstawie: C. Meckseper, Kleine Kunstgeschichte der deutschen Stadt im Mittelalter, Darmstadt 1982, s. 186 i n.
} 
podwyższony potem w XV w. o szachulcową kondygnację. Specjalny typ budowli to zamek miejski, taki, jaki zachował się w Krems - przejęty w latach 40. XIII w. przez sędziego miejskiego Gozzo (pierwsza wzmianka o Gozzoburg pochodzi z 1258 r.). W 1320 r. część tej budowli stała się własnością Habsburgów, część zastawiono. Późniejszy ratusz to jednak kilka domów darowanych mieszczanom w $1419 \mathrm{r}$.

Najważniejsze wnętrza ratusza to sale rady i sądu, w ratuszu mieściła się również czasami sala ceremonialna. W Akwizgranie w XIV w. dawna pałacowa sala Karola Wielkiego została przebudowana przez miasto na salę ratuszową $\mathrm{z}$ zamiarem przeznaczenia jednego $\mathrm{z}$ wnętrz na królewską ucztę koronacyjna. Charakterystyczna nazwa Pfalz dla ratusza w Strasburgu świadczy o przypominającej wnętrze palatium reprezentacyjnej sali rady, mieszczącej się w drugiej kondygnacji. Czasem ratusz to jedynie najbardziej ozdobny, wyższy od pozostałych dom w zwartej zabudowie pierzei rynkowej, jak w Münster, gdzie funkcjonował pierwotnie jako kamienny budynek kalenicowy, cofnięty od pierzei rynkowej o $12 \mathrm{~m}$, wzniesiony jednak na przeznaczonej dla niego podwójnej parceli o wielkości 14,5 x $18 \mathrm{~m}$. Jego fasada, pierwotnie barwna i złocona, ze szczytem z 1335 r., zwrócona była w nieprzypadkowy sposób prosto na katedrę św. Piotra i Pawła i pałac biskupi, wskazując biskupowi niezależność mieszczan od jego jurysdykcji.

Inny typ budowli na obszarze niemieckim to ratusz wolno stojący, powstały z przekształcenia dawnego domu kupców z wielką sala $\mathrm{w}$ drugiej kondygnacji. Ta forma budowli była na obszarze niemieckim najczęstsza. Jednym z wcześniejszych przykładów takiego typu jest ratusz w Minden (1260 r.) - jednocześnie najstarszy przykład gotyckiej architektury monumentalnej w Westfalii, usytuowany dosłownie na granicy okręgu zamkowego (Burgbezirk). W Brunszwiku dwuskrzydłowa budowla gotycka - wymieniona po raz pierwszy w 1302 r., w latach 1393-1396 rozbudowana do dzisiejszej formy - to oczywista mieszczańska opozycja do książęcego zamku Dankwarderode i katedry, tym bardziej znacząca, że w dolnej kondygnacji mieściła arsenał. W Norymberdze ratusz powstał po 1322 r. w wyniku przekształcenia zespołu mieszczańskich domów i wybudowania wielkiej sali pod kierunkiem miejscowego budowniczego Philippa Grossa. Historia niektórych budowli jest bardzo skomplikowana, tak jak ma to miejsce w Brunszwiku, gdzie ratusz z dwoma skrzydłami i dwiema galeriami powstał w 2 fazach - pod koniec XIV i na początku XV w. Z kolei ratusz w Lubece, pewien pierwowzór dla ratuszy północnoeuropejskich, mimo wcześniejszego pochodzenia poszczególnych części składowych swój ostateczny, dziś niemal symboliczny kształt uzyskał w 1435 r. Wtedy 
powstał blendowy szczyt, naśladowany później w jeszcze okazalszej formie w innych miastach Północy, np. w Rostocku.

\section{Miejsce budowli ratuszowych w pejzażu urbanistycznym. Miasta na korzeniu antycznym w obszarze niemieckim}

W latach 1135-1142 wymienia się koloński „domus in quam cives conveniunt" - usytuowany w samym centrum dawnego antycznego miasta Colonia Claudia Ara Agrippinensium i jednocześnie, jak wspomina dokument z 1149 r., w samym centrum dzielnicy żydowskiej (il. 1). Budynek ten jednak nie zachował się do dzisiaj (była to dwukondygnacyjna budowla romańska wzniesiona na dawnych murach rzymskich), a obecna budowla pochodzi już z okresu po 1330 r. Wieża ratusza - zbliżona forma do ówczesnych flandryjskich beffrois - powstała w latach 1407-1413. Ta część budowli, projektowana przez budowniczego pełniącego również przez pewien czas funkcję burmistrza, przeznaczona była do przechowywania miejskich przywilejów i listów zastawnych ${ }^{11}$. Usytuowana na antycznym fundamencie budowla ratusza kolońskiego w sposób oczywisty wydaje się nie tylko symbolicznie, ale i faktycznie związana z pierwocinami samorządowego ustroju miasta powstałego jako Colonia Agrippa już około 38 r. p.n.e., a po otrzymaniu ius Italicum znanego jako Colonia Claudia. Przypomnijmy, że w 364 r. n.e. cesarz Walentynian I ulokował tu obrońce praw miejskich (defensor civitatis), a nagrobek Mascliniusa Maternusa edyla, duumwira i „burmistrza” (curator civitatis) Kolonii rzuca światło na ukształtowany $\mathrm{w}$ tym czasie system cesarsko-samorządowy, tak charakterystyczny dla czasów późnego antyku, z duumwirami (wymiar sprawiedliwości), edylami (policja i budownictwo), kwestorami i kapłanami, wolnymi obywatelami (cives), osadnikami (incolae, peregrini) i niewolnikami ${ }^{12}$.

Taki fundament prawny miał też swoje przestrzenne odniesienia. Ratusz w Kolonii wzniesiony został na miejscu antycznego praetorium u wylotu drogi z późnorzymskiego mostu z 310 r. n.e. i w centrum

${ }^{11}$ C. Dietmar, Die Chronik Kölns, Dortmund 1991, s. 132; A. Wrede, Neuer Kölnischer Sprachschatz. Lexikon der Kölner Mundart, Köln 1984, t. 2, s. 369 (dane za: http://de.wikipedia.org/wiki/Rathaus; 2 IV 2013).

${ }^{12}$ O. Doppelfeldt, Köln von der Spätantike bis zum Karolingerzeit, w: Vor- und Frühformen der europäischen Stadt im Mittelalter. Bericht über ein Symposium in Reinhausen bei Göttingen vom 18. bis 24. April 1972, cz. 1, red. H. Jankuhn, W. Schlesinger, H. Steuer, Göttingen 1973, s. 113, 115, il. 1, 2. 
merowińskiego i frankijskiego osadnictwa z IX w., jednocześnie w centrum tak ważnego dla miast średniowiecznych, a wczesnego w Kolonii, osadnictwa żydowskiego. W średniowiecznym mieście koloński ratusz przyjął również funkcję symboliczna jako usytuowany w połowie osi łączącej postantyczne baptysterium katedry i ottoński kościół NMP na Kapitolu, wzniesiony na miejscu dawnej świątyni Jupitera, Junony i Minerwy. Ratusz usytuowano też na osi północ-południe, łączącej kościół p.w. św. Marcina - na południu, oraz kaplicę św. Kolumby z Sens i późniejszy kościół tego wezwania, wymieniony po raz pierwszy w 980 r. - po stronie północnej. Taka sytuacja nabiera szczególnego znaczenia, jeżeli przyjęlibyśmy dla niej konotacje tzw. crux viarum tym mocniej, że wszystkie wymienione wyżej kolońskie kościoły należą do mitu założycielskiego miasta. Tak na przykład kaplica św. Kolumby - męczenniczki z końca III w. - miała być poprzedniczką kolońskiej katedry, a kościół p.w. św. Marcina, według Chronicon Sancti Martini Coloniensis, powstał jako kaplica w 690 r., na miejscu rzymskiego horreum, a przez świętych mężów Plechelma i Otgera miał być przekształcony w klasztor w $708 \mathrm{r}$. Te informacje pochodza jednak dopiero z osiemnastowiecznej kroniki ${ }^{13}$. W rzeczywistości budowla powstała około 960 r. ${ }^{14}$ Kościół w obecnym kształcie powstać miał po pożarze Kolonii w 1150 r. i na początku XIII w. za opata Szymona ${ }^{15}$.

Usytuowanie ratusza w Ratyzbonie (Regensburg) wydaje się również niezwykle znamienne. Obóz Castra Regina zbudowany został za cesarza Marka Aureliusza i jego syna Kommodusa w 179 r. n.e. Mury miały $545 \mathrm{~m}$ długości, $10 \mathrm{~m}$ wysokości i $2,4 \mathrm{~m}$ grubości. Od wewnątrz znajdował się szeroki na $10 \mathrm{~m}$ wewnętrzny wał, agger, służący komunikacji obrońców, a od zewnątrz były fosy. Podczas najazdu Alemanów w III w. mur został zniszczony i później ponownie go odbudowano ${ }^{16}$. Ratyzbona była główną siedzibą bawarskich Agilofingów, a od VIII w. biskupstwa. Tzw. Altes Rathaus pochodzi w swojej najstarszej części

${ }^{13}$ M. Hasak, Die Kirchen Gross St. Martin und St. Aposteln in Köln, „Die Baukunst” 11, 1899, s. 10; O. Oppermann, Kritische Studien zur älteren Kölner Geschichte I. Die Fälschungen des Oliver Legipont zur Überlieferung von St. Martin, „Westdeutsche Zeitschrift für Geschichte und Kunst” 19, 1900, s. 271-344.

${ }^{14}$ Die kirchlichen Denkmäler der Stadt Köln. St. Gereon, St. Johann Baptist, Die Marienkirchen, Gross St. Marin, red. H. Rathgens, oprac. źródeł J. Krudewig, Düsseldorf 1911 (Die Kunstdenkmäler der Rheinprovinz, t. 7, cz. 1: Die Kunstdenkmäler der Stadt Köln, t. 2, cz. 1), s. 354.

${ }^{15}$ A. Ditges, Groß St. Martin in Köln. Eine Festschrift zur siebenten Säculärfeier der Kirchweihe am 1. Mai 1872, Köln 1872, s. 17.

${ }^{16}$ K. Dietz, T. Fischer, Die Römer in Regensburg, Regensburg 1996, s. 89-94. 
z XIII w. ${ }^{17} \mathrm{~W}$ tym czasie powstała wysoka wieża, stanowiąca odpowiedź na podobne mieszczańskie siedziby wieżowe tego miasta. Obok usytuowano czterokondygnacyjną budowlę administracyjną. Budynek wzniesiono $\mathrm{w}$ miejscu znaczacym - przy narożniku północno-zachodnim rzymskiego kasztelu w kupieckim obszarze miasta (il. 2). Drugie skrzydło budowli - miejski Tanzsaal, późniejszy Reichssaalbau uzupełnione zostało w latach 1335-1350 o zbudowany przez członków ratyzbońskiej strzechy katedralnej wykusz kapliczny, który skierowany był w stronę małego placu usytuowanego tuż przy dawnych obwarowaniach rzymskiego castrum. Ratuszowy portal wejściowy z początku $\mathrm{XV}$ w. (około 1410 r.) skierowany jest pod katem 45 stopni w stronę katedry ratyzbońskiej.

Ukazane na tym portalu symboliczne przedstawienie Schutz und Trutz (,obrona i atak”) - jak nazywaja je ratyzbończycy - z obrazem broniących murów miejskich żołnierzy, ilustruje stały, znany z dziejów tego miasta konflikt między biskupem a władzami komunalnymi i jednocześnie dumę wolnego miasta Rzeszy (il. 3). Przywileje miasto otrzymało od Konrada Szwabskiego i Fryderyka II w 1207 i 1230 r., a w $1245 \mathrm{r}$. z rąk tego ostatniego uzyskało prawo rady i burmistrza ${ }^{18}$. Mieszczaństwo, wzmocnione w 1255 r. ucieczką książąt Bawarii do Landshut, żyło jednak nadal w stałym konflikcie z biskupem i książętami Bawarii. Pod figurami portalu umieszczono herb miasta $\mathrm{z}$ dwoma kluczami, symbol św. Piotra - patrona miasta, a na węgarze portalu umieszczono symbole miar miejskich - stopy, łokcia i sążnia. Ukośne ustawienie portalu kształtuje oś widokową w stronę wznoszonej w tym czasie zachodniej fasady katedry. Balustrada portalu ma swoje ratyzbońskie odniesienie w architekturze domów i wież mieszkalnych, gdzie podobne detale pojawiają się jako specyficzne loggie w kaplicznych kondygnacjach tych budowli ${ }^{19}$. Swoistym pendant dla ukośnego ustawienia portalu ratuszowego była zaprojektowana około 1400 r. trójkątna hala wejściowa katedry (na podobieństwo pochodzącej z około 1330 r. hali katedry w Erfurcie), wznoszona przy udziale znaczacego mistrza architektury gotyckiej Wenzela Roriczera. Na trójkątnym

${ }^{17}$ Datowanie budowli za: Regensburg und die Oberpfalz, red. J. Drexler, A. Hubel, München 1991 (Georg Dehio Handbuch der Deutschen Kunstdenkmäler. Bayern, 5), s. $554-557$.

${ }^{18}$ K.-O. Ambronn, Der Kampf um die Macht 1180-1245 oder das Werden der Kommune, w: Regensburg im Mittelalter, t. 1: Beiträge zur Stadtgeschichte vom frühen Mittelalter bis zum Beginn der Neuzeit, Regensburg 1995, s. 64-65.

${ }^{19}$ R. Strobe, Mittelalterliche Bauplastik am Bürgerhaus in Regensburg. Fester, Portale, Rippengewölbe, Tübingen 1981, s. 33, il. p. 46, 47. 
symbolicznym postumencie katedry wystawiać miano relikwie, miasto na drugim końcu takiej osi symbolicznej ukazywało w portalu ratuszowym siłę swojej niezależności od władz kościelnych ${ }^{20}$. Istotna również w tym przykładzie jest gra dwóch fasad starego i nowego ratusza oraz tworząca punkt zaczepienia dla kompozycyjnej diagonali wieża starego ratusza. Takie wzajemne przeciwstawienie sobie budowli ratusza i katedry nabiera szczególnego znaczenia wobec zauważonego już przez Mieczysława Zlata częstego zwrócenia fasady ratuszowej z wykuszem kaplicznym w stronę wschodnia, co jeszcze mocniej lokuje tę budowlę $\mathrm{w}$ dyskursie symbolicznym z budowlą katedralna ${ }^{21}$.

\section{Ratusz na obszarze niemieckim w mieście bez korzeni antycznych}

Lokalizacja ratuszy w układach przestrzennych miast obszaru niemieckiego zakładanych na „surowym korzeniu” związana jest z lokalizacja kościoła parafialnego. W miastach zakładanych w południowo-zachodnich Niemczech w XII w. przez dynastię Zähringen miejscem usytuowania pierwotnych budowli komunalnych było rozszerzone skrzyżowanie dwóch głównych arterii komunikacyjnych miasta. Jednak właściwa reprezentacyjna budowla ratuszowa powstała we Fryburgu Bryzgowijskim na placu wytworzonym wtórnie przy kościele św. Marcina dopiero w 1303 r., a jeszcze bardziej reprezentacyjny dom kupiecki powstał na południe od fryburskiego Münsteru dopiero w XV w. ${ }^{22}$

W górniczym Freibergu ratusz wzniesiony przy bocznej pierzei centralnie położonego rynku usytuowany jest na osi między kościołem p.w. św. Mikołaja wzniesionym w starszym obszarze miasta a kościołem p.w. św. Piotra w młodszym, Górnym Mieście (il. 4). Obie te budowle skomunikowane sa z rynkiem wąskimi uliczkami prowadzącymi wprost na bryłę budowli komunalnej. Ratusz staje się wobec powyższego symbolicznym zwornikiem „starego” i „nowego” ${ }^{23}$. Podobny przykład

${ }^{20}$ A. Hubel, M. Schuller, Der Regensburger Dom, Regensburg 2008 (wyd. 2 rozsz.), s. 24-26. Budowa gotyckiej murowanej katedry rozpoczęła się jednak już po pożarze budowli romańskiej w 1273 r. K. Pöllath, „Patrizierburgen” in Regensburg. Zu Begriff, Entwicklung und Funktion, w: Burgen und Schlösser in und um Regensburg. Beiträge des 27. Regensburger Herbstsymposions für Kunst, Geschichte und Denkmalpflege vom 23. bis 25. November 2012, red. L.-M. Dallmeier, E. Trapp, Regensburg 2013, s. 43.

${ }^{21}$ M. Zlat, Ratusz - zamek mieszczan..., s. 24.

${ }^{22}$ R. Eysymontt, Kod..., s. 128-129.

${ }^{23}$ K. Blaschke, Kirchenorganisation und Kirchenpatrozinien als Hilfsmittel der Stadtkernforschung, w: tenże, Städteforschung, Stadtkernforschung. Forschungen 
to Görlitz, gdzie ratusz usytuowany jest dokładnie na Dolnym Rynku, między starszym ośrodkiem z kościołem p.w. św. Piotra a kościołem franciszkanów w Górnym Mieście ${ }^{24}$. Również ratusz w Rochlitz stanowi niezwykle ważny element w wydłużonej osiowej kompozycji miasta.

\section{Ratusz na Półwyspie Apenińskim}

Jak pisze Halina Manikowska, rola ratuszy w pejzażu miast włoskich równa była roli katedry: „W pejzażu tych miast zanim w XV i XVI w. powstały ogromne pałace signorów, władców księstw, w które przeobraziły się miasta-państwa, dominowały dwie zwłaszcza budowle: katedra i palazzo comunale z towarzysząca mu potężną wieżą - siedziba władz komuny miejskiej, nazwana tu nie ratuszem, nie hôtel de ville, ale pałacem" 25 . Ważnym impulsem do powstawania komun na Półwyspie Apenińskim był pokój w Konstancji w 1183 r. Cesarz Fryderyk Barbarossa nadał wówczas miastom przywileje komunalne, co pozwoliło wykorzystać siłę ekonomiczną okręgów miejskich, tzw. contadi, tworzyć budowle komunalne i organizować przestrzeń urbanistyczną dla życia publicznego. Siedziby władz komunalnych samą swoją nazwą palatium civitatis podkreślały suwerenność komuny - pojęcie palatium przypisane było bowiem pierwotnie jedynie siedzibie cesarzy i ich namiestników, a wcześniejsze siedziby komunalne nosiły bardziej przyziemne określenie domus, turris, arengarium. Jednak, jak wskazuje Manikowska, dopiero w początku XIII w. zaczęto wznosić okazałe pałace oddalone od katedry i siedziby biskupiej ${ }^{26}$. Po okresie od końca XII w.

zur Entstehung mitteleuropäischer Städte. Ausgewählte Aufsätze, oprac. J. Uwe, red. P. Johanek, Köln-Wien 1987, il. 1, 8, 12.

${ }^{24}$ Tamże, s. 18. R. Eysymontt, Kod..., s. 167.

${ }^{25}$ H. Manikowska, Średniowieczne miasta-państwa na Pótwyspie Apenińskim, w: Rozkwit średniowiecznej Europy, red. H. Samsonowicz, Warszawa 2001, s. 251. O ratuszu środkowoeuropejskim w odniesieniu do przykładów głównie pochodzących z obszaru Włoch i jego symbolicznej funkcji jako „zamku mieszczan” wcześniej pisał M. Zlat, Ratusz - zamek mieszczan..., s. 13-36.

${ }^{26}$ H. Manikowska, dz. cyt. s. 252-253. W 1966 r. György Korompay na łamach KAU zauważał kilka modeli kształtowania placów miejskich $\mathrm{w}$ średniowiecznych Włoszech. Pierwszy z nich związany był z sytuowaniem siedziby władzy komunalnej przed kościołem - na miejscu dawnego atrium i baptysterium. Sam kościół usytuowany był zazwyczaj przy murach miejskich, a place zakładane być miały na planie litery „L”, potem „U”. Poszerzenie kompetencji komuny miejskiej spowodować miało powstanie nowych placów komunalnych. Od XII w. władza zaczyna przenosić się na arengo (miejsce zgromadzeń), a potem do ratusza $\mathrm{z}$ salą kolumnową na piętrze i otwartą salą kolumnową w przyziemiu. Obok często sytuowano loggia pubblica. 
do połowy lub lat 80 . XIII w. komuna zarządzana była przez podestę - urzędnika zatrudnianego często do określonych celów administracyjnych - często pochodzącego spoza zarządzanego obszaru. Dopiero w końcu XIII w. władze przejmuje zwycięski popolo, a palazzo comunale staje się palazzo del popolo ${ }^{27}$.

Szczególnie dobra egzemplifikacją tej sytuacji są niezwykle charakterystyczne ratusze toskańskie. Noszą one zazwyczaj nazwę palazzo della Signoria lub palazzo del popolo. Nieustanna walka między zwolennikami władzy cesarskiej - gibelinami, i zwolennikami władzy papieskiej - gwelfami, powodowała, że budowle te przybierały formę obronnych zamków. Najznaczniejszy z toskańskich ratuszy, Palazzo Vecchio, rozpoczęto budować w 1299 r., a zasiadający (i mieszkający) w nim najwyżsi urzędnicy komuny, priorzy cechów i chorąży sprawiedliwości, zwani „panami” (signori), tworzyli Signoria, stąd pałac ten zwany był Palazzo della Signoria. Poprzednikiem i architektonicznym pierwowzorem dla najbardziej znanej florenckiej budowli komunalnej był Palazzo dei Priori w Wolterze, którego budowę rozpoczęto w 1208 r., i Palazzo dell'Imperatore w Prato, wzniesiony dla Fryderyka II w latach 1238-1249. Palazzo Vecchio miał też swojego poprzednika w samej Florencji - był nim pałac podesty, później zwany Bargello, wzniesiona między 1255 a 1261 r. pierwsza siedziba „ludowych” władz komunalnych Florencji, rozbudowana w latach $1280-1346$, z 54-metrową wieżą ${ }^{28}$.

Ożywiony w XIV w. proces powstawania kolonii miast dominujacych (Siena, Florencja, Piza) sprawił, że budowle komunalne nowych miast (borghi) były kopiami ratuszy w miastach macierzystych. Nawet w „starym” Montepulciano, od końca XIV w. podporządkowanym polityce Florencji, piętnastowieczny ratusz jest kopią Palazzo Vecchio.

Nowy plac komunalny usytuowany miał być poprzecznie do głównego ciagu komunikacyjnego. W XIII w. następować też miało w przestrzeni miasta podkreślenie bryły ratusza razem z jego schodami. Podział na partię papieską (gwelfów) i cesarską (gibelinów) stanowić miał o wzajemnym ustawieniu ratusza i katedry. Jeżeli miasto było gibelińskie, ratusz stał naprzeciwko katedry, jeżeli gwelfickie, obok tej budowli. G. Korompay, Ksztattowanie głównych placów miejskich we Wtoszech w okresie średniowiecza, tłum. W. Galewski, KAU 11, 1966, nr 1, s. 27-42.

${ }^{27}$ Dziełem pierwszego mediolańskiego podesty „cudzoziemskiego” (forestiero), Umberto Viscontiego z Piacenzy, był podział kompetencji zgodny z kryterium terytorialnym (1186/1187). System ten np. uzależniał liczbę radnych od liczby bram. Przekazano też magistratowi jurysdykcję na obszarze poza murami, utrzymywanie ulic i wskazywano konieczność ponoszenia konkretnych kosztów finansowych sprawowania władzy, zob. P. Brezzi, Societá feudale e vita cittadina, t. 2: La civiltá del medioevo europeo (814-1190), Roma 1972, s. 540; H. Manikowska, dz. cyt., s. 306.

${ }^{28}$ G. Gaeta Bertelà, Nationalmuseum Bargello der offizielle Führer, Florenz 2001, s. 50 . 
Innym wyrazem świadomego traktowania przez władze komunalne nie tylko pojedynczych monumentalnych obiektów, ale i całych zespołów urbanistycznych była kontrola wysokości wież w murach miejskich. Zwycięstwo popolo we Florencji pociagnęło za soba nakaz zburzenia wyższych części, wystających ponad koronę murów obronnych wież feudałów ${ }^{29}$. Nie zdarzyło się tak jednak wszędzie, na co dowodem San Gimignano ${ }^{30}$.

San Gimignano to miasto poddane początkowo dominacji biskupa Volterry, niezależne od 1199 r., ważny punkt na drodze między Siena a Florencja, usytuowany na głównym trakcie komunikacyjnym półwyspu, Via Francigena ${ }^{31}$. Od bitwy pod Monatperti w 1260 r. miasto współdziałało ze Siena, w 1300 r. zostało zapisane przez Dantego Alighieri (jako posła Florencji) do Ligii Gwelfickiej i potem, od 1353 r., poddane całkowicie Florencji. Największy rozwój przeżywało jednak już w XII i XIII w., a przekazy źródłowe wskazują na wspomaganie tego procesu przez kontrolujacego regulacje układu komunikacyjnego z crux viarum podeste $e^{32}$. Miasto miało również, podobnie jak Siena, już w połowie XIII w. przepisy o maksymalnej szerokości domów, która nie mogła przekraczać 12 łokci (braccia). Monumentalne budowle świadczą o dominacji politycznej w poszczególnych okresach rozwoju San Gimignano. Pałac komunalny realizowany był w dwóch etapach od 1288 r. na terenie dawniej należącym do rodu Ardinghelli i obszarze z wcześniej stojącymi tu domami rodziny Ruggerotti-Montagutolo. Jego pierwsza kondygnacja związana jest z architektura Pizy. Górna kondygnacja, oddzielona gzymsem, już o lżejszych proporcjach i oparta na zasadzie sieneńskich ostrych łuków ${ }^{33}$. Nowy pałac miejski zakończono budować w 1291 r., wieżę wznoszono od 1298 r. i umieszczono

${ }^{29}$ H. Manikowska, dz. cyt., s. 361.

${ }^{30} \mathrm{O}$ San Gimignano, Orvieto i Genui pisałem już w artykule Średniowieczne miasto idealne we Wtoszech, „Quart. Kwartalnik Instytutu Historii Sztuki Uniwersytetu Wrocławskiego" 2010, nr 3 (17), s. 18-38.

${ }^{31}$ Informacje na temat San Gimignano za: E. Guidoni, Storia urbanistica w: Atlante Storico delle Città Italiane. Toscana, t. 5: San Gimignano, red. E. Guidoni, Roma 1997.

${ }^{32} \mathrm{O}$ rozwoju miasta świadczy między innymi wzrost długości murów od $1108 \mathrm{~m}$ $\mathrm{w}$ X w. do $2176 \mathrm{w}$ połowie XII w. D. Balestracci, Immigrazione e morfologia urbana nella Toscana bassomedievale, w: D'une ville à l'autre. Structures matérielles et organisation de l'espace dans les villes européennes (XIIIe-XVIe siècle). Actes du colloque organisé par l'École française de Rome avec le concours de l'Université de Rome (Rome 1er-4 décembre 1986), red. J.C.M. Vigueur, Rome 1989, s. 88.

${ }^{33}$ G. Casali, Elementi del repertorio architettonico tardo medievale toscano a Vico Pisano, Castelfranco di Sotto, Cascina e S. Gimignano, w: D'une ville à l'autre..., s. 741-757. 
na niej wielki dzwon, dotąd znajdujący się na wieży kościoła parafialnego. Budowa wieży z zawieszonym na niej herbem podesty ukończona została w 1311 r. Budowla wzniesiona nad ulica della Costarella była $\mathrm{w}$ tym czasie symbolem sieneńskiej dominacji nad miastem. Około 1300 r. można w odniesieniu do San Gimignano mówić o centralnej przestrzeni publicznej miasta. Znakiem jej wzbogacenia była także budowa około 1299 r. monumentalnych schodów przed kościołem parafialnym (Ranieri da Colle). Najważniejszym aspektem kompozycyjnym placu wydaje się diagonala prowadząca od wejścia z przedmieścia San Matteo - od strony drogi z Florencji ${ }^{34}$. Przestrzenną dyspozycję placu $\mathrm{z}$ zaznaczeniem osi diagonalnych usytuowanych $\mathrm{w}$ stosunku do siebie pod kątem 45 stopni porównuje się z Lukka, z jej pałacem komunalnym obok kościoła św. Michała. Enrico Guidoni podkreśla także rolę wieży komunalnej dzwonnicy jako kompozycyjnego łącznika dwóch fasad o podobnej szerokości (fasada katedry św. Marcina i budynek pałacu komunalnego). Podobne rozwiązanie zastosowano w Pistoi (il. 5). Akcentowanie diagonali wydaje się zreszta jednym z najważniejszym motywów kompozycji miasta średniowiecznego również na północ od Alp.

Podobny model kompozycji przestrzennej Guidoni widzi także we florenckiej Piazza della Signoria, nie zauważa go natomiast w Sienie. $\mathrm{Z}$ drugiej strony, jak pisze Wacław Ostrowski, Siena sama w sobie prezentuje świetny przykład kontaktu wzrokowego między Palazzo Pubblico a katedra ${ }^{35}$.

\section{Orvieto}

Orvieto - etruskie miasto usytuowane na kamiennej platformie - to przykład nieładu uporządkowanego ${ }^{36}$. Rozwój miasta podzielić można na następujące etapy:

1. VI/VIII w. - cytadela wczesnośredniowieczna i pierwsze jądro miejskie;

${ }^{34}$ E. Guidoni, Storia urbanistica..., s. 32.

${ }^{35} \mathrm{~W}$. Ostrowski, Wprowadzenie do historii budowy miast. Ludzie i środowisko, Warszawa 2001, s. 139-140.

${ }^{36}$ Informacje poniższe podaję za: A. Satolli, Peculiarità dell'urbanistica orvietana nel Medioevo, „Bollettino dell'Istituto Storico Artistico Orvietano” 39, 1983, s. 105-168. W polskiej literaturze najwięcej o Orvieto pisał T. Tołwiński, Urbanistyka, t. 1: Budowa miasta w przeszłości, Warszawa 1948, s. 71-80. Wskazywał on osiowa kompozycję ulicy Maitani, prowadząca do fasady katedry, jako zwiastun tendencji nowożytnych, omawiał też osiowy układ miasta oparty na głównej jego arterii - Corso Cavour - i architektoniczną obudowę głównych miejskich placów. 
2. IX-X w. - rozwój miasta wzdłuż dłuższej osi założenia;

3. XI-XII w. - powstaje crux viarum, 10 kościołów, w 1029 r. jest już ich 14, w $1171 \mathrm{r}$. notuje się 5 bram miejskich;

4. między 1200 a 1275 r. - formowanie miasta dwubiegunowego $\mathrm{z}$ centrum świeckim i centrum religijnym;

5. koniec XIII w. - można wyróżnić trzy części miasta: pierwsza z pałacem i placem komunalnym, druga z Piazza i Palazzo del Popolo, trzecia z katedra i pałacem biskupim;

6. od połowy XIV w. następuje faza „procesji i klasztorów”.

W wyniku owego wielofazowego rozwoju powstaje pozornie bezładny plan miasta. Najważniejsza z punktu widzenia symboliki przestrzeni miasta w Orvieto jest idealnie prosta ulica łączacca taras Palazzo del Capitano del Popolo z Palazzo dei Sette. Ten ostatni kompleks budowli z 47-metrowa wieża, zwaną od XVI w. „del Moro”, należał początkowo do rodu związanego z biskupem Orvieto. I tu, podobnie jak w San Gimignano, wieża stanowi „oś obrotu kompozycji” - kierując się od niej na wschód, docieramy do placu przed katedra z identycznym niemal jak komunalny, jednak już biskupim pałacem.

Poza układami diagonalnymi istnieja we Włoszech oczywiste przykłady frontalnego przeciwstawienia sobie katedry i ratusza. Tak jest z ratuszem w Cremonie, który usytuowany jest naprzeciw katedry, a tablica inskrypcyjna na jego fasadzie informuje o fundacji cesarskiej Fryderyka Hohenstaufa ${ }^{37}$. Oczywista kontynuacja takiego dwubiegunowego lokowania symbolu władzy biskupiej i samorządu pojawiła się również w prywatnym mieście papieskim - piętnastowiecznej Pienzy Piusa II (Eneasza Sylwiusza Piccolominiego).

\section{Miasta portowe obszaru śródziemnomorskiego}

Genua to miasto usytuowane w zatoce między Półwyspem Apenińskim i Alpami, określane często jako typowy przykład potęgi morskiej ${ }^{38}$. Ślady epoki rzymskiej w Genui nie są liczne. Mury z 864 r. otoczyły teren o powierzchni 22 ha, te wzniesione w latach $1155-1166$ opasuja obszar o powierzchni 65 hektarów ${ }^{39}$. Gęsto zabudowane miasto nie

${ }^{37}$ Inskrypcja odnosi się do rozbudowy Palazzo Comunale w 1245 r., kiedy Cremona należała do stronnictwa procesarskiego.

${ }^{38}$ W. Braunfels, Abendländische Stadtbaukunst. Herrschaftsform und Baugestalt, Köln 1991 (wyd. 6), s. 74. Zob. też: E. Mazzino, T. Ossian De Negri, Il centro storico di Genova, Genova 1974.

${ }^{39}$ L. Benevolo, Miasto $w$ dziejach Europy, tłum. H. Cieśla, Warszawa 1995, s. 49. 
ma wielkich placów, a siedem dzielnic skupia się wachlarzowato na wybrzeżu. O związku z morzem świadczy też usytuowanie w $1260 \mathrm{r}$. przez mającego pełnię władzy nad miastem kapitana ludu Guglielma Boccanegry pałacu komunalnego (późniejszy Palazzo San Giorgio), wzniesionego częściowo $\mathrm{z}$ materiału pochodzącego $\mathrm{z}$ rozebranego przez genueńczyków pałacu podesty weneckiego w Konstantynopolu (Palazzo del Pantocratore) w czasie powrotu Paleologa do stolicy cesarstwa. Na głównej bramie oraz na prawym i lewym rogu fasady tej budowli wmurowano pochodzące z tegoż pałacu weneckiego trzy lwie głowy, zdobyte $\mathrm{w}$ walce $\mathrm{z}$ odwiecznym wrogiem, podkreślające dumę Genui. Usytuowanie pałacu komuny - na nabrzeżu portowym, w oddaleniu od katedry - miało także symbolizować niezależność od biskupa ${ }^{40}$. Tłem dla pałacu jest wspaniały, podobnie jak $\mathrm{w}$ Pizie, waterfront $\mathrm{z}$ fasadami domów wypełnionymi potężnymi arkadami ${ }^{41}$. To również symbol skutecznie prowadzonej do 1380 r. rywalizacji z Wenecja.

Symboliczną niemal sytuację przestrzenną ratuszy prezentuja przynależne również do kultury włoskiej miasta dalmackie: Split, Zadar, Korčula, Hvar ${ }^{42}$. W Zadarze usytuowane niemal naprzeciw siebie sa: renesansowa loggia wzniesiona przez Giangirolamo san Micheli w 1568 r. i budynek straży miejskiej z wieżą zegarową z 1562 r. ${ }^{43}$ W Korčuli ratusz wzniesiono w 1525 r. ukośnie w stosunku do portyku stojacej naprzeciw katedry. W Splicie ratusz z 1443 r., usytuowany poza stanowiącym jądro układu miejskiego pałacem Dioklecjana, zwrócony jest swoją fasadą $\mathrm{z}$ loggią ukośnie w stosunku do murów pałacu, a w związku $\mathrm{z}$ tym prosto $\mathrm{w}$ stronę starego portu. Portowy charakter miasta podkreślony jest więc nie tyle usytuowaniem na nabrzeżu budowli komunalnej, ile jej „wektorem zwrotu”. O świadomości urbanistyczno-architektonicznej władców miasta świadczy sam umieszczony na fasadzie herb przedstawiający mury pałacu Dioklecjana z widniejąca pośrodku wieżą katedry. Wprost $\mathrm{w}$ stronę portu zwrócona jest renesansowa miejska loggia $\mathrm{w}$ Hvarze, usytuowana na zachodnim

${ }^{40} \mathrm{O}$ historii portu w Genui ostatnio: B. Hryszko, R. Hryszko, Obraz miasta portowego na przykładzie ikonografii Genui na przełomie średniowiecza i czasów nowożytnych, w: Polis, urbs, metropolis. Materiaty LIX Ogólnopolskiej Sesji Naukowej Stowarzyszenia Historyków Sztuki, Lublin, 25-26 listopada 2010, red. L. Lameński, E. Błotnicka-Mazur, Warszawa 2011, s. 75-90.

${ }^{41}$ L. Benvolo, dz. cyt., il. 15.

${ }^{42}$ Podstawowe dane dla dziejów architektury gotyckiej i romańskiej Dalmacji podaje W. Molè, Sztuka Stowian południowych, Wrocław-Warszawa-Kraków 1962, s. $177-197$.

${ }^{43}$ A. Travirka, Zadar. History, Culture, Art Heritage, Zadar 2010, s. 18. 
brzegu placu, wzmiankowana już w XIII w. i związana ze statutami portu z 1331 r. Symbolem politycznej przynależności sa dwa weneckie Lwy przed budowlą autorstwa Tripuna Bokanicia z XVI w.

\section{Miasta planowe Półwyspu Apenińskiego}

Do szczególnej grupy, również jeżeli chodzi o lokalizację ratuszy, należą nuovi borghi, powstałe w wyniku prowadzonej w latach 1284-1306 i potem wznowionej jako conquista del contado walki o prymat militarny i polityczny florenckiej komuny ze szlachta na terenie dolin Arno i Mugello ${ }^{44}$. Jeden z najbardziej interesujacych przykładów przestrzennej funkcji ratusza $\mathrm{w}$ nuovi borghi przynosi miasto Scarperia, broniące przejścia przez Apeniny w dolinie Mugello (il. 6). Niezwykłe jest tu ukształtowanie głównej osi miasta wzdłuż linii będącej jednocześnie osią funkcjonalną i symboliczną prowadzoną od murów miejskich, poprzez dziedziniec ratusza, aż do bryły kościoła parafialnego. Linia ta łączy wnętrze dziedzińca ratusza - jako wnętrze publiczne o ograniczonym dostępie - z przestrzenią publicznego otwartego placu między kościołem i siedzibą władzy komunalnej.

W San Giovanni Valdarno (Castel San Giovanni) - założonej w ostatnich latach XIII w. florenckiej terra nuova, której centrum zgodnie z góry przyjętym planem urbanistycznym i społecznym zamieszkiwane było przez dawnych feudalnych poddanych, wieśniaków z osad Vacchereccia, San Martino, Pianalberti i Ricasoli zasiedlających z góry przeznaczone im ulice - ratusz usytuowano $\mathrm{w}$ geometrycznym centrum miasta, a jego loggię - naprzeciw skrzyżowania jego cardo i decuma$n u s^{45}$. Po rozbudowie ratusza w 1408 r. zamieszkali w nim wikariusze, rekrutujący się spośród patrycjuszowskich rodzin florenckich. Oś prowadzona między górująca nad loggią wieżą i masywem kościoła parafialnego jest też najważniejszą osią kompozycyjną miasta.

\footnotetext{
${ }^{44} \mathrm{Na}$ ten temat: R. Eysymontt, Kod..., s. 147-153, tam dalsza literatura. Wśród nowszych prac: Borghi nuovi e borghi franchi nel processo di costruzione dei distretti comunali nell'Italia centro-settentrionale (secoli XI-XIV), red. R. Comba, F. Panero, G. Pinto, Cherasco-Cuneo 2002; I centri minori della Toscana nel Medioevo. Atti del convegno internazionale di studi (Figline Valdarno, 23-24 ottobre 2009), red. G. Pinto, P. Pirillo, Firenze 2013.

45 Już w połowie XVI w. Giorgio Vasari doskonały, zamknięty kształt urbanistyczny florenckich nuovi borghi przypisywał florenckiemu architektowi Arnolfo di Cambio, zob. G. Vasari, Żywoty najsławniejszych malarzy, rzeźbiarzy $i$ architektów, tłum. K. Estreicher, Warszawa 1980, s. 135.
} 


\section{Wieże ratuszowe Flandrii}

Jak pisał Leonardo Benevolo: „W planach miast, podobnie jak i w planach katedr, zostaje uwzględniona trójwymiarowość, która zezwala w razie potrzeby na uzasadnione odstępstwa, zapewnia ciagłość zamysłu i w dużym stopniu spaja poszczególne elementy" ${ }^{\prime 6}$. Uwarunkowania urbanistyczne określane mianem „osnowy horyzontalnej” dla ratusza gdańskiego analizowała Teresa Zarębska ${ }^{47}$. Pisała ona, że budowle komunalne były eksponowane w głębi perspektywy ulicy, nawet jeżeli pojawiały się w pejzażu ulic prowadzonych łukiem (Alberti pisał, że ulice wijące się nad rzeka pozwalają na oglądanie głównych fasad tak, jakby były skierowane na środek ulicy $)^{48}$. Takie wrażenie robią oczywiście w pejzażu miejskim głównie wieże ratuszowe, których wysokość i wspaniałość konkurowała z wieżami kościołów farnych.

$\mathrm{Na}$ obszarze Flandrii budowle pełniące funkcje ratusza podzielić trzeba na trzy co najmniej osobne architektonicznie zjawiska - wcześniejsze trzynastowieczne hale, beffrois i pojawiające się dopiero od początku XIV w. domy ławników oraz miejsca sprawowania władzy administracyjnej i sądowniczej. Tak np. w Brugii ławnicy początkowo, do około 1280 r., zasiadający w beffroi przenieśli się później do ghyselhus na tzw. Burg - budowli rozebranej w 1376 r., aby stworzyć miejsce pod właściwy ratusz, scepenhuus (franc. hôtel de ville) - z zachowana do dzisiaj wielka wielofunkcyjna sala zebrań. W innych jednak ośrodkach, na przykład w Leeuw (Léau), halles aux draps służyły sukcesywnie jako sala ławników, hala tkanin, jatki i miejsce zebrań gildii.

Najważniejszą z budowli komunalnych miast flamandzkich były wieże, wspomniane już beffrois - symbolizujace miejskie wolności, tu przechowywano pieczęcie miejskie, klucze do miasta i jego przywileje. Umieszczony na beffroi dzwon oznajmiał czas zamknięcia i otwarcia bram miejskich, początek i koniec targu, a strażnik ostrzegał o pożarach. Rozbiórka wieży lub zdjęcie dzwonu było książęca karą za nieposłuszeństwo miasta. Budowli tej towarzyszyły zwykle hale. Według dotychczasowej literatury beffroi charakterystyczne było jedynie dla Flandrii, Hainaut i Tournais ${ }^{49}$. Marjan Buyle pisze, że nie występowały one nawet w Brabancji, gdzie podobne funkcje pełnić miała wieża kościelna ${ }^{50}$.

${ }^{46}$ L. Benevolo, dz. cyt., s. 83.

${ }^{47}$ T. Zarębska, dz. cyt., s. 53-77.

${ }^{48}$ Takie spostrzeżenie powtarzam za T. Zarębska, tamże, s. 55.

${ }^{49}$ Tak pisze M. Buyle, Les edifices publics, w: tenże [i in.], Architecture gothique en Belgique, red. M. Buyle, Bruxelles 1997, s. 170.

${ }^{50}$ Tamże. 
Najstarsze beffroi wzniesiono w Tournai, a jego budowa rozpoczęła się w 1188 r. zgodnie z przywilejem króla Francji Filipa Augusta, nadającym miastu „prawo dzwonu”: umieszczenia go „w miejscu dogodnym, by zwoływać mieszczan, kiedy sprawy miasta będą tego wymagały". W 1294 r. wieloboczne wieżyczki otoczyły romański korpus, podwajając jego wysokość. Stał się on wzorem dla wielu innych podobnych budowli51.

Beffroi w Brugii istniało już w 1280 r., choć trudno jest dokładnie wykazać, które z części prostokątnej podstawy wieży pochodza z XIII w.; najwyższe kondygnacje wieży pochodzą z lat 1482-1486. Charakterystycznym elementem przestrzeni średniowiecznej Brugii było wyraźne ukierunkowanie głównych ulic na najwyższe akcenty pionowe miasta, z których wyróżniało się oczywiście beffroi-miejska dzwonnica. Wieża ta zamykała zarówno perspektywę prowadzącej od północy, czyli od kanału łączącego z portem, Vlamingstraat (platea Flammingorum), jak i od południa, od strony bramy św. Katarzyny, czyli Eechoutstraat. W przedstawieniach tego miasta, np. panoramie bitwy pod Beverhoutsveld pod Brugia w $1382 \mathrm{r}$. według piętnastowiecznej miniatury z rękopisu Kronik Froissarta z berlińskiej Staatsbibliotheek, dominacja beffroi jest doskonale widoczna. Taka dominacja w wedutach miejskich wydaje się zupełnie oczywista wobec faktu, że właśnie przed tą budowla w 1267 r. podpisano umowę Brugii z Hanzą. Wieża nosiła również najważniejsze miejskie emblematy, jej szczyt początkowo zwieńczony był monumentalną figura św. Michała, a od 1502 r. flandryjskim Lwem.

Następne z budowli komunalnych miast flandryjskich - ratusze - były początkowo domami ławników. Najstarszy z nich na terenie Flandrii wzniesiony został w Aalst (Alost) około 1225 r. Jego cecha charakterystyczna jest bryła zbliżona $\mathrm{w}$ formie do korpusu zamku zaopatrzonego w cztery narożne wieżyczki. Sklepienia dolnych, najstarszych części budowli sa jeszcze romańskie, podziały elewacyjne zbliżone są do podziałów zachowanych domów romańskich w Tournai, choć zwieńczenia otworów sa już ostrołuczne. Pewnym wzorem tego typu późniejszych budowli jest dom ławników w Brugii, wzniesiony na terenie Burg (dawnego grodu) w latach 1376-1386 - na planie prostokata z wysokimi oknami, narożnymi wieżyczkami i postumentami pod figury. Wielka sala na drugiej kondygnacji nakryta była sklepieniem lub stropem. Druga z sal tej kondygnacji służyła jako pomieszczenie sądu, co potwierdzone było często odpowiednimi scenami w dekoracji wnętrza. Dlatego ławnicy w Brugii nakazali w 1388 r. namalowanie malarzowi Janowi Coene sceny Sąu Ostatecznego, podobne malowidło zamówiło

\footnotetext{
${ }^{51}$ Tamże.
} 
u Dirka Boutsa Louvain, a Roger van der Weyden na ratuszu w Brukseli namalował scenę sądu Trajana i Herkenbalda (niezachowana). Sale mieściły wielkie kominki z rzeźbami przedstawiającymi herby, postacie historyczne i biblijne. Czasem, tak jak w Kortrijk (Courtrai), dekoracje stanowiły mapy zarządzanego przez miasto obszaru.

Następną fazą wznoszenia ratuszy we Flandrii był wiek XV. Przykład stanowi tu ratusz w Brukseli, którego budowę rozpoczęto w $1401 \mathrm{r}$. Dodanie nowego skrzydła w 1444 r. stworzyło prawie symetryczna, dwuskrzydłową kompozycję. Ta nowa budowla była materialnym znakiem wzrostu znaczenia Brukseli i przywódczej od tego momentu roli Brabancji, w której miasto to przejęło dawną stołeczna funkcję Louvain. Rangę architektoniczno-urbanistyczna ratusza lepiej zrozumieć, jeśli przypomni się, że murowaną formę otrzymały budynki otaczajace rynek brukselski dopiero po bombardowaniu w $1695 \mathrm{r}$.

Podobnie jak Brugia, wielofazowo rozwijała się także Gandawa. Policentryczny zrazu charakter Gandawy związany był z trzema ośrodkami mającymi swoje antyczne poczattki: terenem na południowym brzegu rzeki Leie (Lys), na południe od późniejszego zamku hrabiów Flandrii (Gravensteen), terenem na lewym brzegu rzeki Skaldy, związanym z późniejszą katedrą św. Bawona, i terenem związanym z kościołem św. Makarego, położonym na wschód od ujścia Leie do Skaldy. W tym ostatnim obszarze osadnictwo miasta było najstarsze - sięgało czasów antycznych i epoki frankijskiej.

Istota trzynasto- i czternastowiecznej reformy urbanistycznej Gandawy był intensywny rozwój miasta w miejscu usytuowanym między Gravensteenem a starym Portusem (osada handlowa). Centrum tej nowej osady stał się kościół p.w. św. Mikołaja. Wzniesienie beffroi, zaprojektowanego w latach 1300-1323, nieco na południe od kościoła - ukończonego w 1377 r. miejskiego symbolu władzy i znaku jego przywilejów, z wielkim dzwonem (o nazwie Roland), oznajmiającym nie tylko początek i koniec dnia roboczego, ale i ostrzegającego przed niebezpieczeństwem - było znakiem przejęcia większości kompetencji władczych przez samorząd. Od tego momentu gandawskie beffroi stało się symbolem miasta, jak widać to chociażby w tle miniatury pokazującej hołd mieszkańców Gandawy oddawany księciu Filipowi w 1458 r., będącej jednocześnie najstarszą podobizna miasta (Österreichische Nationalbibliothek w Wiedniu). Ranga beffroi w kompozycji pejzażu miasta zaznacza się również na panoramicznym widoku Gandawy z 1524 r.: beffroi tworzy wspólnie z wieżami kościoła św. Bawona i kościoła św. Mikołaja najważniejszą wertykalną grupę trójwymiarowej kompozycji. Wieże te sa jednocześnie znakiem nowej funkcji 
centrum miejskiego, po jego przeniesieniu z najbliższego sąsiedztwa zamku hrabiów Flandrii, Gravensteen (il. 7, 8).

U stóp gandawskiego beffroi znajduja się sukiennice, Lakenhalle. Wzniesione między 1425 a 1441 r., w dolnej kondygnacji mają salę o 20 kolumnach, pochodzących z wcześniejszej czternastowiecznej budowli; górna kondygnacja mieściła założoną w 1613 r. Gildię św. Michała.

Trzecia z kolei budowla komunalna - gandawski stadhuis - została wzniesiona w wyniku co najmniej 11 kampanii budowlanych. Powstanie trzeciej już z kolei siedziby administracji wynikało m.in. z zapisów traktatu z Senlis z 1301 r., który dzielił władzę między dwa kolegia ławników, każde zasiadać miało w osobnym budynku. Schepenen van de Keure sprawowali władze administracyjna, zajmowali sie sprawami finansowymi i karnymi, schepenen van de Gedele zajmowali się jedynie kwestiami sukcesji władzy i sprawami charytatywnymi. Pierwszy budynek, Keure, był tylko narożnie usytuowana jednokondygnacyjna budowlą z wnętrzem nakrytym dwunawowym sklepieniem beczkowym, wspartym na prymitywnych gotyckich kolumnach. W centrum obecnego budynku najstarsze jego jądro datuje się na $1482 \mathrm{r}$. i nie jest ono widoczne od strony ulicy. Ta część składa się z dwóch umieszczonych nad sobą sal przekształconych w połowie XIX w. Obecnie mianem stadhuis w Gandawie określa się budowlę wzniesiona w latach 1519-1539 przez Rombouta II Keldermansa i Dominika de Waghemakare z przedstawieniami hrabiów Flandrii na fasadzie. Zrealizowany w 1580 r. tylko w jednej czwartej renesansowy budynek komunalny nosi nazwę Bollaertskamer. Proces budowy zakończony został ze zlecenia schepenen van de Gedele w stylu późnego renesansu w latach 1595-1618. Budowlę ukończono jednak ostatecznie dopiero w XVIII w., a w 1870 r. poddana została restauracji przez Viollet le Duca.

\section{Ratusze na Śląsku}

Wspomniane wyżej flandryjskie widoki miast kojarzyć można z najsłynniejszymi panoramami miast ślaskich. Najprecyzyjniej rangę średniowiecznej wieży ratusza widać na dwóch przedstawieniach Wrocławia, pierwszym z Kroniki świata Hartmanna Schedla z 1493 r. i drugim - zaginionym obrazie ukazującym Jana Kapistrana na tle średniowiecznej weduty miasta z końca XV w. ${ }^{52}$ Obraz ten przechowywany

${ }^{52}$ Najlepsza reprodukcja tego obrazu w: G. Barthel, „Der Städte Königin. Das Stadtbild Breslaus in der Schau des Künstler”, [Breslau 1944], s. 27 , il. 1 (dzieło nie zostało wydane, posiadam jedynie kopię jego szczotki wydawniczej). 
był niegdyś w zakrystii wrocławskiego kościoła bernardynów. Przedstawiony na nim widok miasta od strony południowej rozciaga się od Bramy Świdnickiej i kościoła św. Elżbiety aż do kościoła św. Krzyża. W związku z potrzebą pokazania całej trójwymiarowej rzeczywistości monumentalnego centrum miasta obiekty do siebie zbliżono. Malarz starał się oddać dość wiernie charakterystyczne elementy architektoniczne, np. łuki oporowe kościoła św. Marii Magdaleny. Dla nas jednak najważniejsze jest to, że wieżę ratusza w tym przedstawieniu ukazano wyraźnie w jego centrum, tuż obok głowy Jana Kapistrana. W obu obrazach autorzy przywiązali dużą wagę do wyeksponowania wysokiego schodkowego wschodniego szczytu budowli.

Związki z Flandrią obdarzonej prawem flamandzkim Nysy były już komentowane ${ }^{53}$. Elementami wspólnymi dla założeń Gravelines i Nysy wydaje się trójkątny rynek i prowadzenie po łuku głównego miejskiego szlaku komunikacyjnego, powiązanego zresztą z przebiegiem dawnego kanału odnogi rzeki ${ }^{54}$.

Analogia między Nysą a największymi miastami Flandrii - Brugia i Gandawą - dotyczy również faktu, że jednym z najważniejszych elementów funkcjonalnych miasta jest przecinający je kanał. Ten w Nysie oczywiście nie miał tak ważnych funkcji komunikacyjnych i transportowych jak gandawskie kanały rzeki Leie, stanowiące podstawę rozwoju miasta między końcem XI a XIII w..$^{55}$, ani kanały rzeki Reie w Brugii. Te ostatnie dopływają aż na zaplecze rynku i w pobliże domów kupców lubeckich i florenckich, główny plac handlowy miasta pierwotnie rozdzielony był właśnie kanałem wodnym, a hale targowe, wzniesione po 1200 r., służyć miały wyładunkom prosto ze statku. Dla nas jednak najważniejszy jest fakt, że widok z kroniki Hartmanna Schedla z 1493 r. ukazuje Nysę w trakcie wznoszenia beffroi, która to robotę zakończono 5 lat później (il. 9).

Miejsce usytuowania ślaskiego ratusza w przestrzeni miasta, podobnie jak we Włoszech czy Flandrii, związane jest ze skrzyżowaniem głównych osi miasta - osi handlowej, poprowadzonej między głównymi bramami miejskimi, i osi sakralnej, poprowadzonej między dwoma najważniejszymi budowlami sakralnymi. Jeżeli ta pierwsza oś prowadzona

${ }^{53}$ R. Eysymontt, Nysa w średniowieczu. Między Gandawa a Opawa, w: Nysa. Sztuka w dawnej stolicy księstwa biskupiego, red. R. Hołownia, M. Kapustka, Wrocław 2008, s. 19-38.

${ }^{54} \mathrm{Za}$ : A. Verhulst, Un exemple de la politique économique de Philippe d'Alsace; la fondation de Gravelines (1163), „Cahiers de Civilisation Médièvale” 10 (37), 1967, s. $15-28$.

${ }^{55}$ P. Lavedan, J. Hugueney, L’urbanisme au moyen âge, Genève 1974, s. 46. 
jest zazwyczaj wzdłuż dłuższej osi geometrycznej założenia, ta druga diagonalna - przebiega zazwyczaj przez środek bloku śródrynkowego. Najlepszy przykład stanowi kompozycja przestrzenna dolnoślaskich Ząbkowic i Wrocławia. W pierwszym wypadku oś symboliczno-sakralna przebiega od prezbiterium kościoła parafialnego do kościoła dominikanów, po drodze trafiając na zespół rynkowych kramów. Tu w bloku śródrynkowym, podzielonym wyraźnie dwiema uliczkami, oś ta trafia w sam środek przecięcia tych uliczek - „krzyż”. Ratusz z kolei, usytuowany idealnie w narożniku południowo-zachodnim kwartału w centrum rynku, stanowi osnowę drugiej najważniejszej diagonali miasta, łączącej tę budowlę i wolno stojąca dzwonnicę kościoła parafialnego. Jego centralne, niemal geometryczne usytuowanie w układzie krzyżowym miasta podkreślone jest także poprzez diagonalę łączacca ratusz i zamek. Wieże kościoła parafialnego i ratusza są tė widocznymi w panoramie miasta zasadniczymi akcentami wertykalnymi układu, co potwierdza nie tylko widok Friedricha Bernharda Wernera z połowy XVIII w., lecz również smutny obraz miasta po pożarze w 1858 r., w którym te dwie wieże wyraźnie wyłaniają się z morza ruin - by krzyczeć niemal do nieba o litość. Zaznaczyć należy również, że ta właśnie przestrzeń rynku, usytuowana między wieżą ratuszową a dzwonnica kościoła w Zabkowicach, określona została w sposób nieprzypadkowy nazwą Grosser Ring lub Ober Ring, podobnie zreszta jak w sasiednich Ziębicach. Dodatkowo w Ząbkowicach lekko ukośne ukierunkowanie ustawienia elewacji ratusza podkreśla, podobnie jak w opisywanej wyżej Ratyzbonie, zwrócenie się fasady ratusza w stronę kościoła parafialnego. Diagonala ta ma więc prawdopodobnie symboliczne znaczenie.

Plan średniowiecznego Wrocławia pozwala wyznaczyć dwie osie diagonalne: ta bardziej oczywista biegnie od ratusza do fary p.w. św. Elżbiety, druga, mniej widoczna z poziomu gruntu, a wspaniale wyczuwalna chociażby na zdjęciu lotniczym, poprowadzona jest od kościoła św. Wojciecha, poprzez kościół św. Marii Magdaleny, dalej ratusz, aż do placu Solnego (il. 10). W takiej sekwencji obiektów mamy niemal historię rozwoju funkcjonalno-architektonicznego obszaru staromiejskiego od najstarszego kościoła parafialnego św. Wojciecha, przejętego w $1226 \mathrm{r}$. przez dominikanów, przez starszą farę miejska, do siedziby władz miejskich - początkowo domu kupieckiego - i dalej do drugorzędnego placu miejskiego.

Specyficzna sytuację kształtowania osi kompozycyjno-komunikacyjnych związanych z kierunkami rozwoju przestrzeni miasta prezentuje wieża ratuszowa w Brzegu. Główna diagonala kompozycyjna przeprowadzona została między kaplica zamkową a kościołem św. Mikołaja, przebiegając jednak zaledwie przez narożnik południowo-zachodni rynku. 
Wzniesienie w latach 1735-1739 obok zamku - na miejscu dawnego kościoła dominikanów, zburzonego w 1541 r. - monumentalnego barokowego kościoła św. Krzyża wzmocniło jeszcze efekt tej diagonali56. Teraz wyznaczona została ona od środka korpusu barokowej świątyni przez wieżę ratusza z 1358 r., przebudowaną w latach 1576-1577, i trafiała dalej w pobliże przeciwległego narożnika rynku ${ }^{57}$. Jednak już wcześniej wieża ta, wieńcząca równoległe do siebie dwa osobne budynki kramów w sposób niemal idealny, stanowiła odpowiednik flandryjskiego beffroi z wszystkimi konsekwencjami takiego symbolicznego spojrzenia. Budowlę projektował Bernard Niuron, opierając się jednak prawdopodobnie na wzorze ratusza w Antwerpii, na co dowodem sa rachunki brzeskiej rady miejskiej z 1567 r. za wysłane do Brzegu rysunki tego dzieła ${ }^{58}$. Interesujące jest również to, że przejście na osi ulicy Garbarskiej i Jabłkowej (oś poprzeczna układu przestrzennego), przebiegające w poprzek bloku śródrynkowego, wypadało dokładnie pod wieżą ratusza.

\section{Podsumowanie}

Miejsce usytuowania ratusza $\mathrm{w}$ mieście średniowiecznym związane było z centralna rola tej budowli w jego systemie politycznym i funkcjonalnym. „Centralność” jednak postrzegana być musi w tej kompozycji na kilka sposobów. Po pierwsze, może być ona związana z klasycznym układem krzyżowym miasta i wówczas ratusz znajduje to samo miejsce, które zajmowało niegdyś praetorium w rzymskim castrum, usytuowane

${ }^{56}$ M. Zlat, Brzeg. Ślask w zabytkach sztuki, Wrocław-Warszawa-Kraków 1973, s. 125.

${ }^{57}$ H. Schoenborn, Geschichte der Stadt und des Fürstentums Brieg. Ein Ausschnitt aus der Geschichte Schlesiens, Brieg 1907, s. 154.

${ }_{58}$ Tak Hans Lutsch pisze o rozpoczynających się w 1567 r. pracach projektowych dot. ratusza brzeskiego: „Darauf deutet die nach den Ratsrechnungen 1567 geleistet Zahlung von 16 Gr. für die Contrafact (Zeichnung, Modell) des Rathauses zu Antorff (Antwerpen...) und $4 \mathrm{Gr}$, für eine größere Contrafact eiusdem praetorii Anturipani”. H. Lutsch, Die Kunstdenkmäler der Landkreis des Reg.-Bezirks Breslau. Im amtlichen Autrage Bearbeitet, t. 2, Breslau 1889, s. 337. Ratusz w Antwerpii wzniesiony został w latach 1560-1565 wg projektu Cornelisa Florisa de Vriend i był często naśladowany w miastach hanzeatyckich. Pisze o tym J. Chrościcki, Antwerpia, Warszawa 1988, s. 9-83, a za nim R. Czerner, Ratusz w Brzegu, Wrocław 1994, s. 92-93. Ostatnia wzmianka w literaturze dotyczacej ratusza brzeskiego to przypuszczenie M. Zlata, jakoby dla inspiracji fundatora do Brzegu przysłany został z Antwerpii sztych Melchisedecha von Hoorena. Ostatecznie projekt ratusza miałby przygotować jednak Bernard Niuron, a zrealizować Jakub Paar. M. Zlat, Sztuka polska. Renesans i manieryzm, Warszawa 2008, s. 257. 
na skrzyżowaniu cardo i decumanus. Po drugie, może być to „centralność" podkreślona jedynie przez zasadniczą rolę głównego akcentu wertykalnego miasta: tak jak ma to miejsce w wypadku rozwiązań zwiazanych z idea flandryjskiego beffroi. Po trzecie, „centralność” zwiąana być może również z „dynamiczną" diagonalną osią kompozycji miasta, która to zreszta sytuacja wydaje się dla miasta średniowiecznego najbardziej charakterystyczna. Podobieństwa między zasadami funkcjonowania budowli ratuszowej w różnych odległych od siebie regionach geograficznych każa powtórzyć za Teresa Zarębską: „[...] celowa jest konfrontacja badanych zespołów ze współczesnymi im koncepcjami i z archetypami funkcjonującymi nawet w odległych geograficznie, lecz bliskich kulturowo obszarach Europy"59.

\section{Bibliografia}

Buyle M., Coomans T., Esther J., Genicot L.F., Architecture gothique en Belgique, Bruxelles 1997.

Eysymontt R., Dawne ratusze we wspótczesnej Europie, w: Rada Miejska przez wieki. Materiaty $z$ konferencji, Wrocław 2008, s. 83-95.

Eysymontt R., Kod genetyczny miasta. Średniowieczne miasta lokacyjne Dolnego Ślaska na tle urbanistyki europejskiej, Wrocław 2009.

Guidoni E., Storia dell'urbanistica. Il Duecento, Bari 1989.

Keller H., Die ostdeutsche Kolonialstadt des 13. Jahrhunderts und ihre südländischen Vorbilder, Wiesbaden 1979.

Korompay G., Kształtowanie głównych placów miejskich we Wtoszech w okresie średniowiecza, tłum. W. Galewski, „Kwartalnik Architektury i Urbanistyki” 11, 1966, nr 1, s. 27-42.

Kruml M., Die mittelalterliche Stadt als Gesamtkunswerk und Denkmal, Wien 1992.

Lavedan P., Hugueney J., L'urbanisme au moyen âge, Genève 1974.

Manikowska H., Średniowieczne miasta-państwa na Pótwyspie Apenińskim, w: Rozkwit średniowiecznej Europy, red. H. Samsonowicz, Warszawa 2001.

Meckseper C., Kleine Kunstgeschichte der deutschen Stadt im Mittelalter, Darmstadt 1982.

Ostrowski W., Wprowadzenie do historii budowy miast. Ludzie i środowisko, Warszawa 2001.

Zagrodzki T., L'nfluence de la tradition antique de la distribution de l'étendue sur le tracé des plans des villes créées au Moyen Âge, w: Mélanges offerts à René Crozet à l'occasion de son 70e anniversaire, Poitiérs 1966.

Zarębska T., Kontekst urbanistyczny ratusza Głównego Miasta w Gdańsku, w: Ratusz w miastach pótnocnej Europy. Materiaty z sesji „Ratusz w miastach

${ }^{59}$ T. Zarębska, dz. cyt., s. 77. 
nadbattyckich", Gdańsk 23-25 XI 1993, red. S. Latour, Gdańsk 1997, s. $53-77$.

Zlat M., Ratusz - zamek mieszczan: symbolika typu architektonicznego $i$ jego form, w: Ratusz w miastach pótnocnej Europy. Materiaty z sesji „Ratusz w miastach nadbattyckich", Gdańsk 23-25 XI 1993, red. S. Latour, Gdańsk 1997, s. $13-36$.

\section{Rafał Eysymontt}

The symbolism of town halls in medieval cities. Selected examples

\section{(Summary)}

Town halls have always been the best example of the aspirations and possibilities of urban communities. The location of the town hall building was related to its central role in the political system and functioning of the town. This was the case, irrespective of the period in which the building was raised, or its size. Its functional and ideological centrality in the urban space was achieved in several ways.

The first, dating back to the ancient tradition, is associated with the classical structure of a city based on a rectilinear grid of streets - the town hall takes the place of the Roman praetorium, which was in the castrum at the intersection of the cardo and decumanus. This was not only the case in cities in the Apennine Peninsula, but also in colonized areas - in the towns established on the former sites of Roman camps. If the town hall building was part of a densely developed area, its form always distinguished it from the other buildings, and if it was a free-standing building, it competed with the church buildings with regards to its shape and location.

Another way of emphasizing the central role of the main municipal building in the urban layout was to make it the main vertical accent, by accentuating its height with regard to the church towers - as in the solutions associated with the Flemish idea of the beffroi.

The third important aspect regarding the spatial composition of medieval cities was the location of the town hall building in close relation to the "dynamic" diagonal axis of the town's layout linking the town hall with the cathedral or parish church. This kind of layout can be found both on the Apennine Peninsula and in Silesia. The significant analogies, which are visible at first glance, between the functioning of various town hall buildings in various geographical regions far away from one another, confirm the appropriateness of undertaking further research on the various groups of buildings in urban layouts both in the context of contemporary ideas and archetypes that had an influence throughout the whole of Europe, which in this context appears to be a culturally homogenous area.

Key words: town hall, urban community, municipal building, symbolism. 


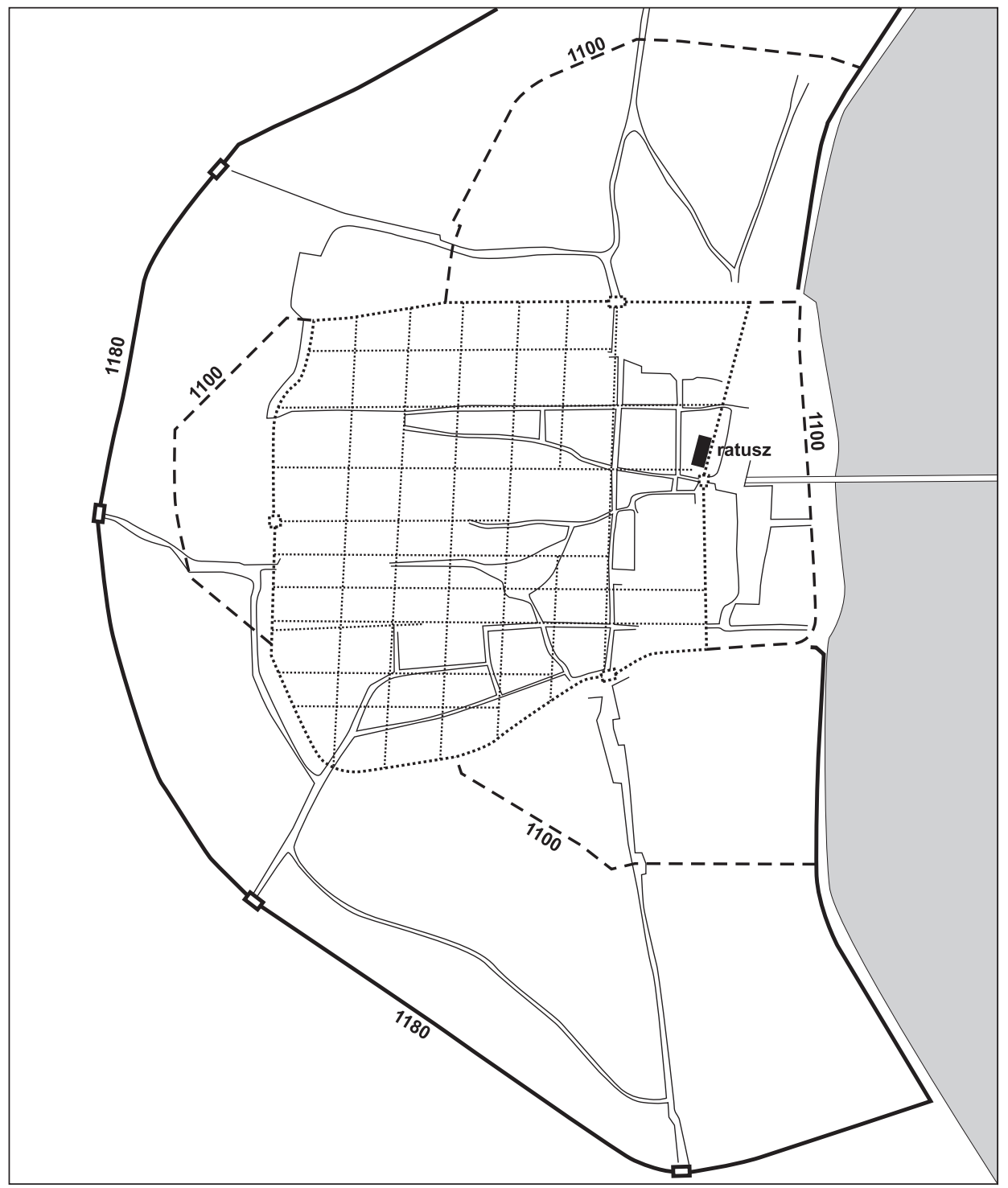

Il. 1. Miejsce usytuowania ratusza kolońskiego oznaczone na planie miasta antycznego; oprac. graf. M. Siehankiewicz 


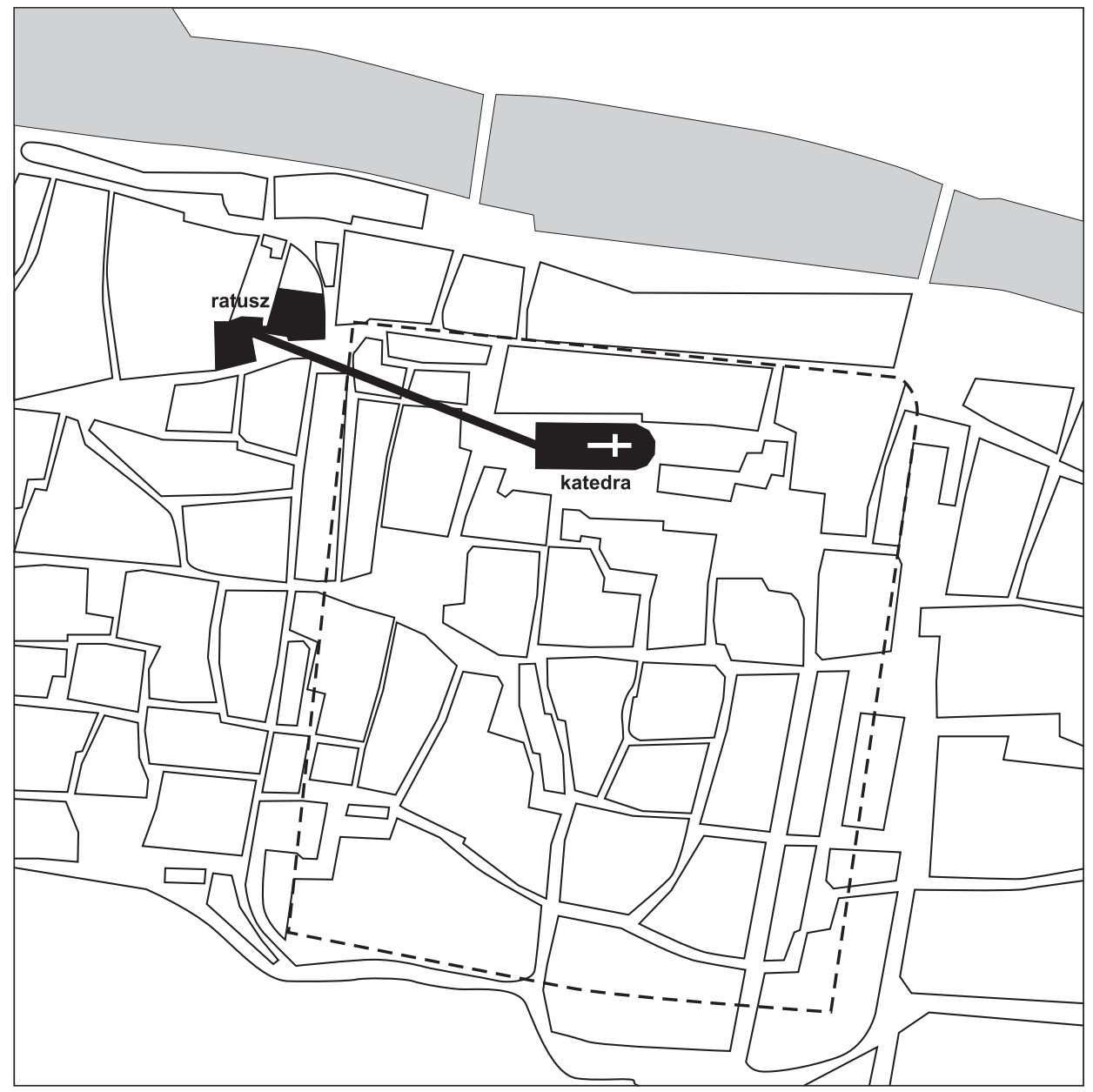

Il. 2. Ratyzbona, oznaczono granice castrum, katedrę i ratusz. Linia łączy portal ratusza i katedry; oprac. graf. M. Siehankiewicz 


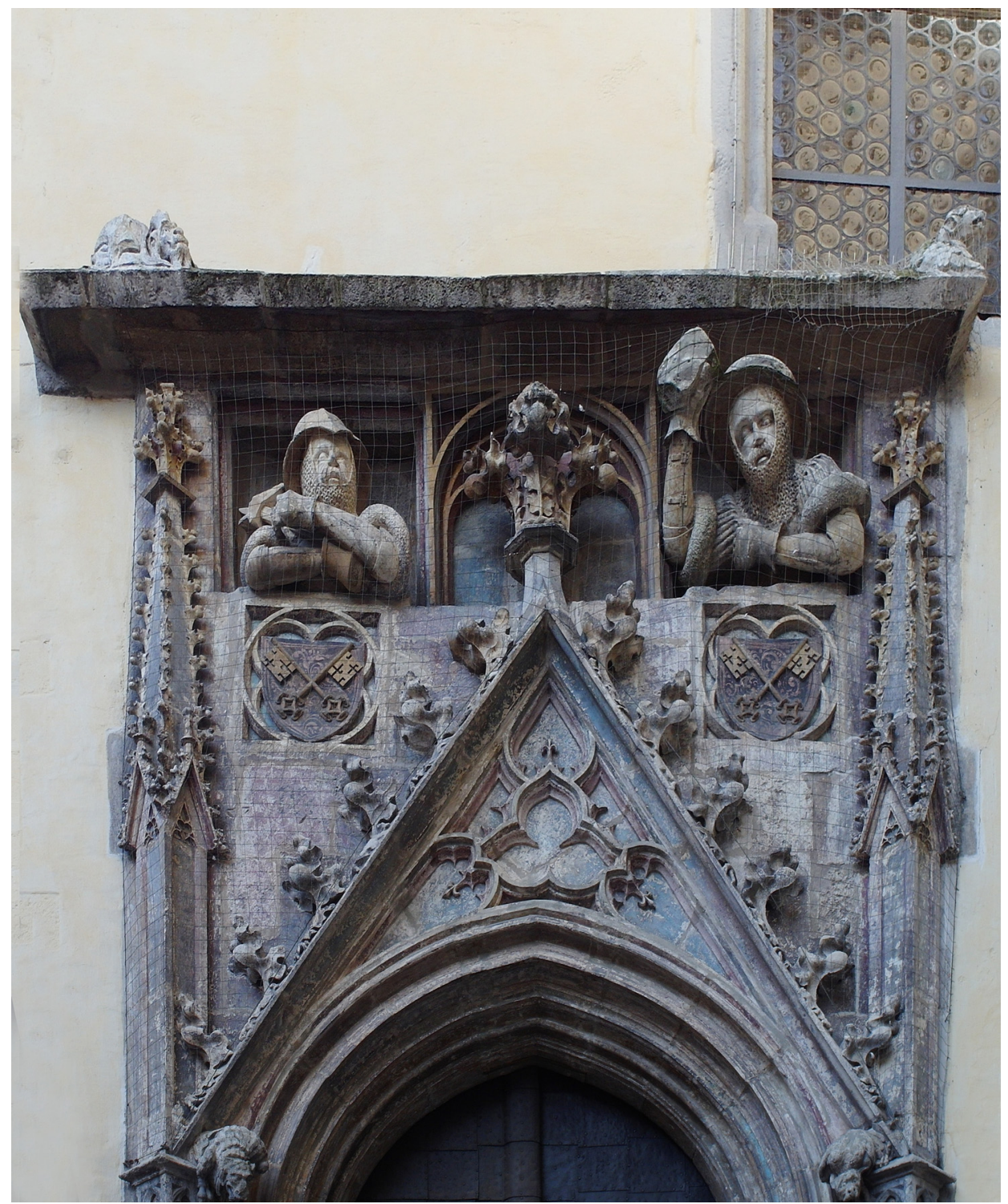

Il. 3. Portal „Schutz und Trutz” ratusza w Ratyzbonie; fot. R. Eysymontt 


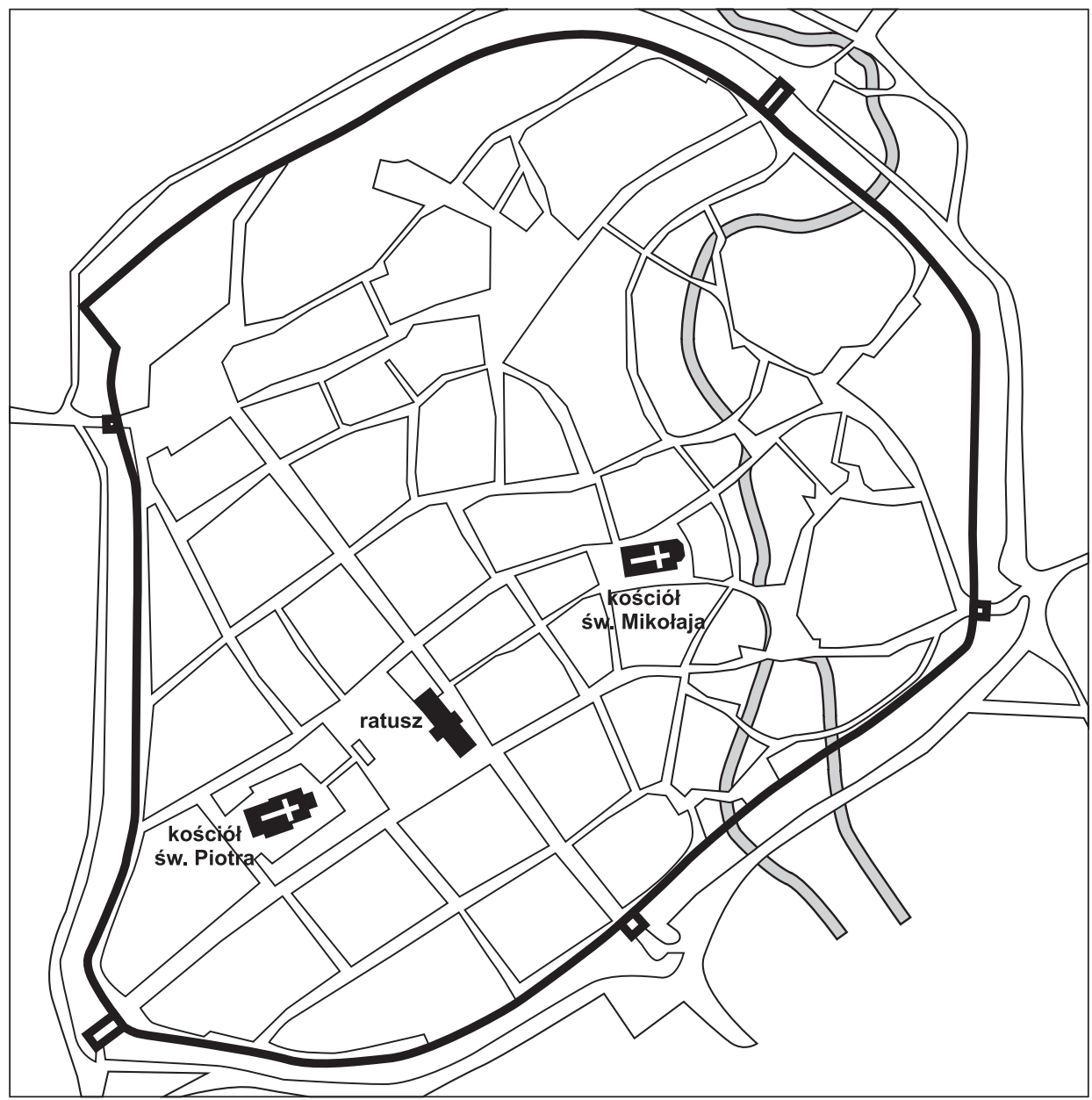

Il. 4. Freiberg an der Saale, oznaczono starszą część miasta z kościołem św. Mikołaja, nowszą z kościołem św. Piotra i ratusz, kościoły i ratusz połączone osobnymi uliczkami; oprac. kartograficzne M. Siehankiewicz 


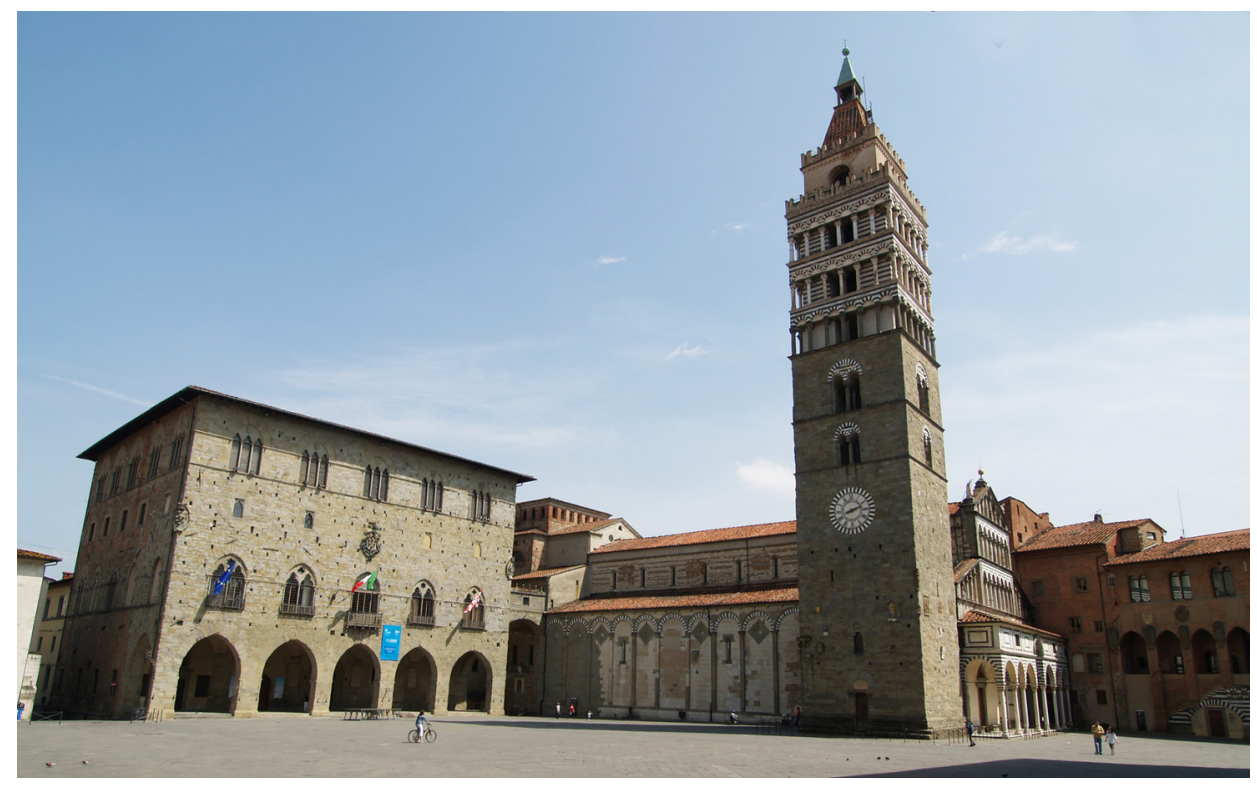

Il. 5. Pistoia, pałac komunalny i katedra; fot. R. Eysymontt

Il. 6. Scarperia, oś kompozycyjna łącząca dziedziniec ratusza i fasadę kościoła; oprac. graf. M. Siehankiewicz

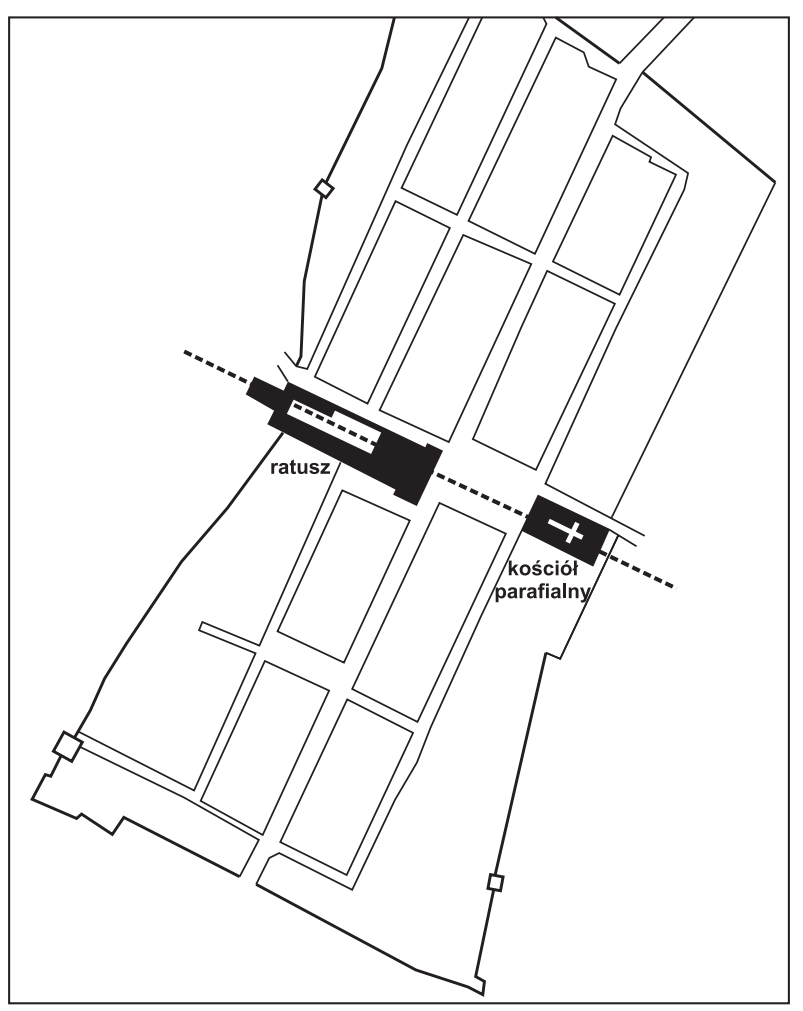




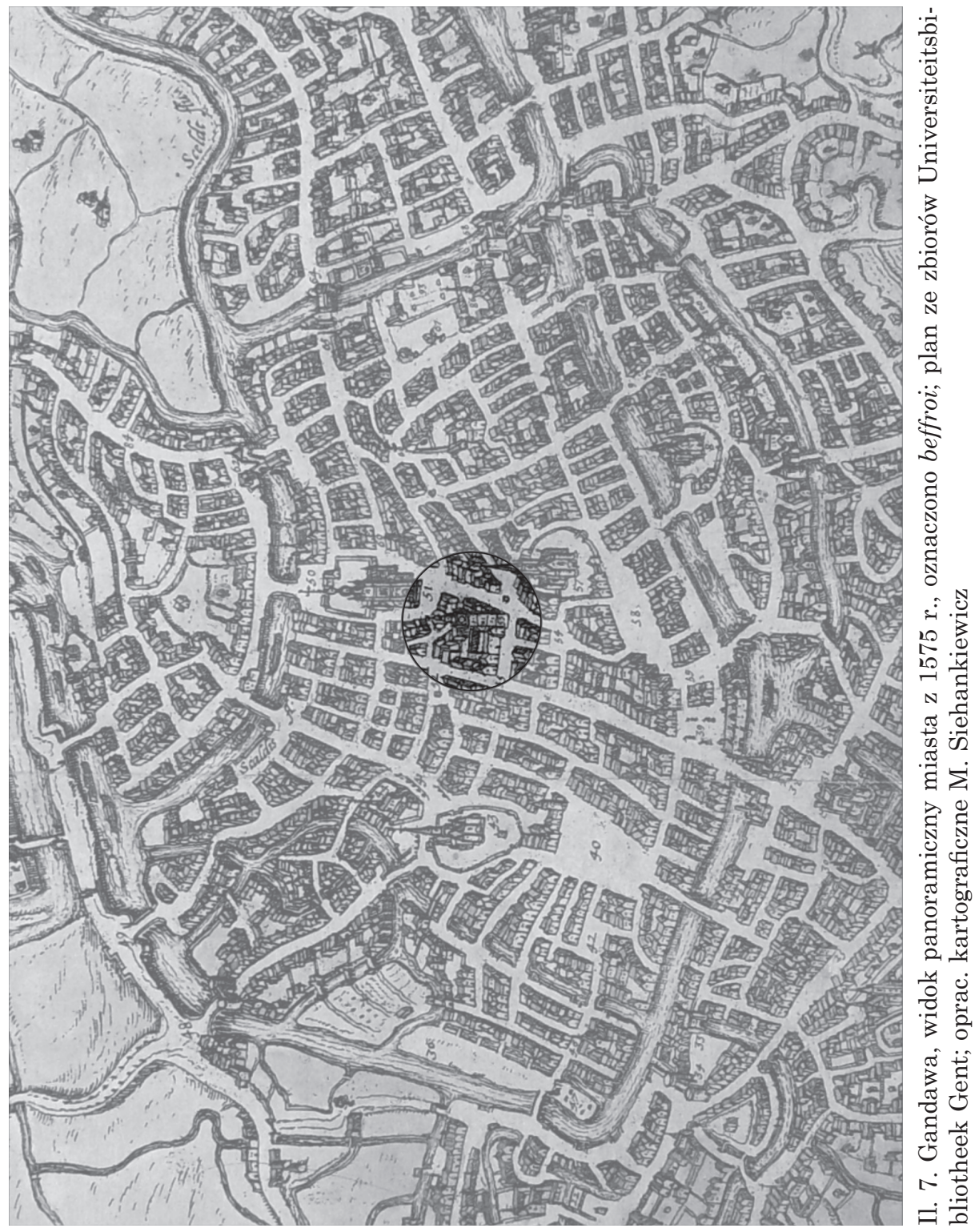




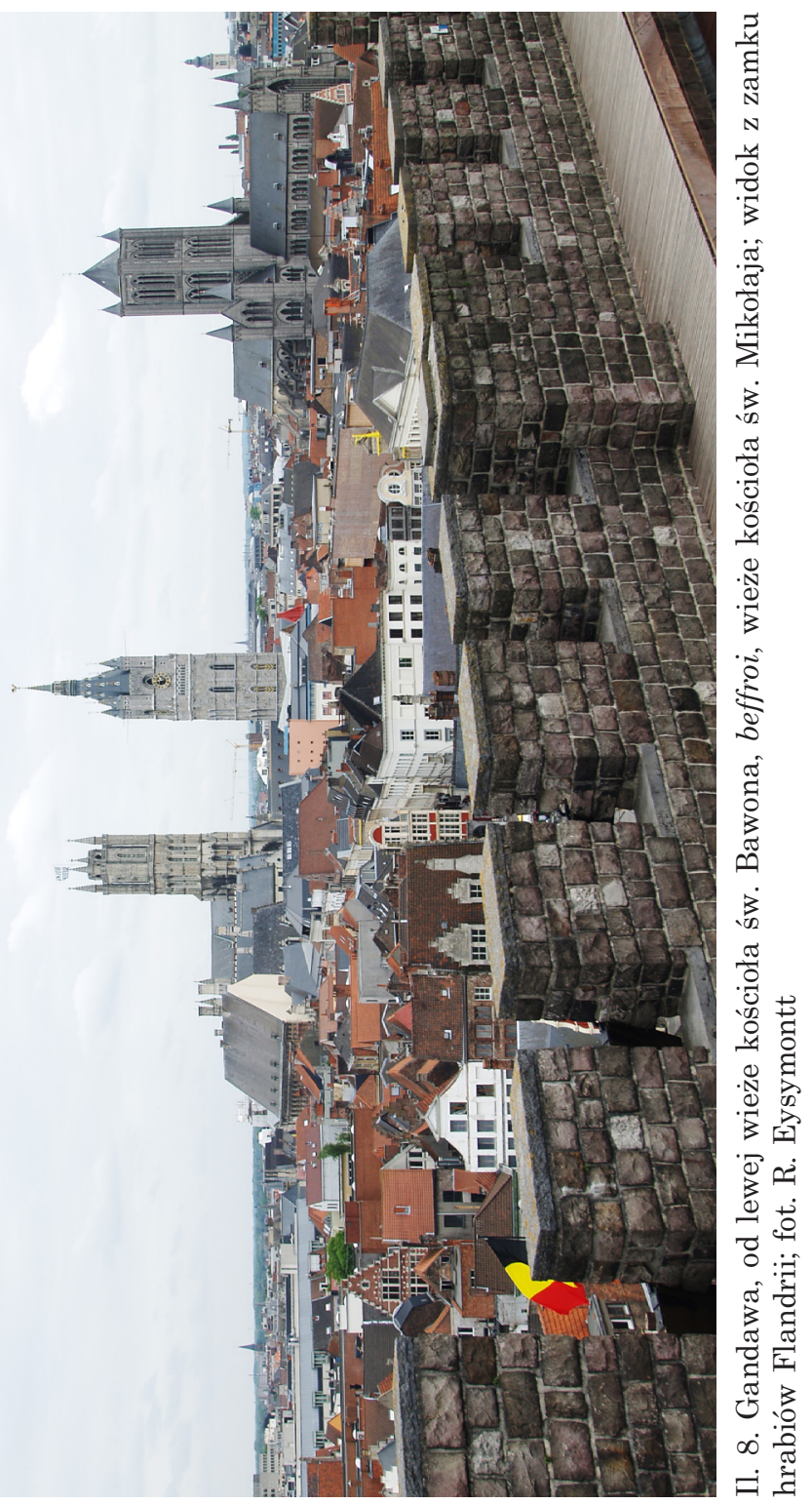




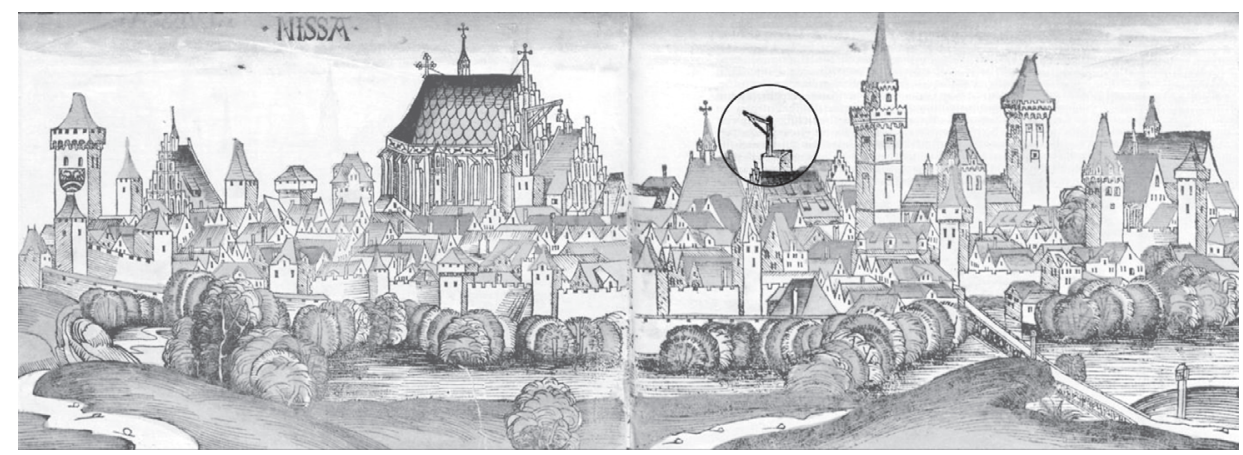

Il. 9. Budowa nyskiego beffroi na panoramie miasta Hartmanna Schedla z 1493 r.; oprac. graf. M. Siehankiewicz

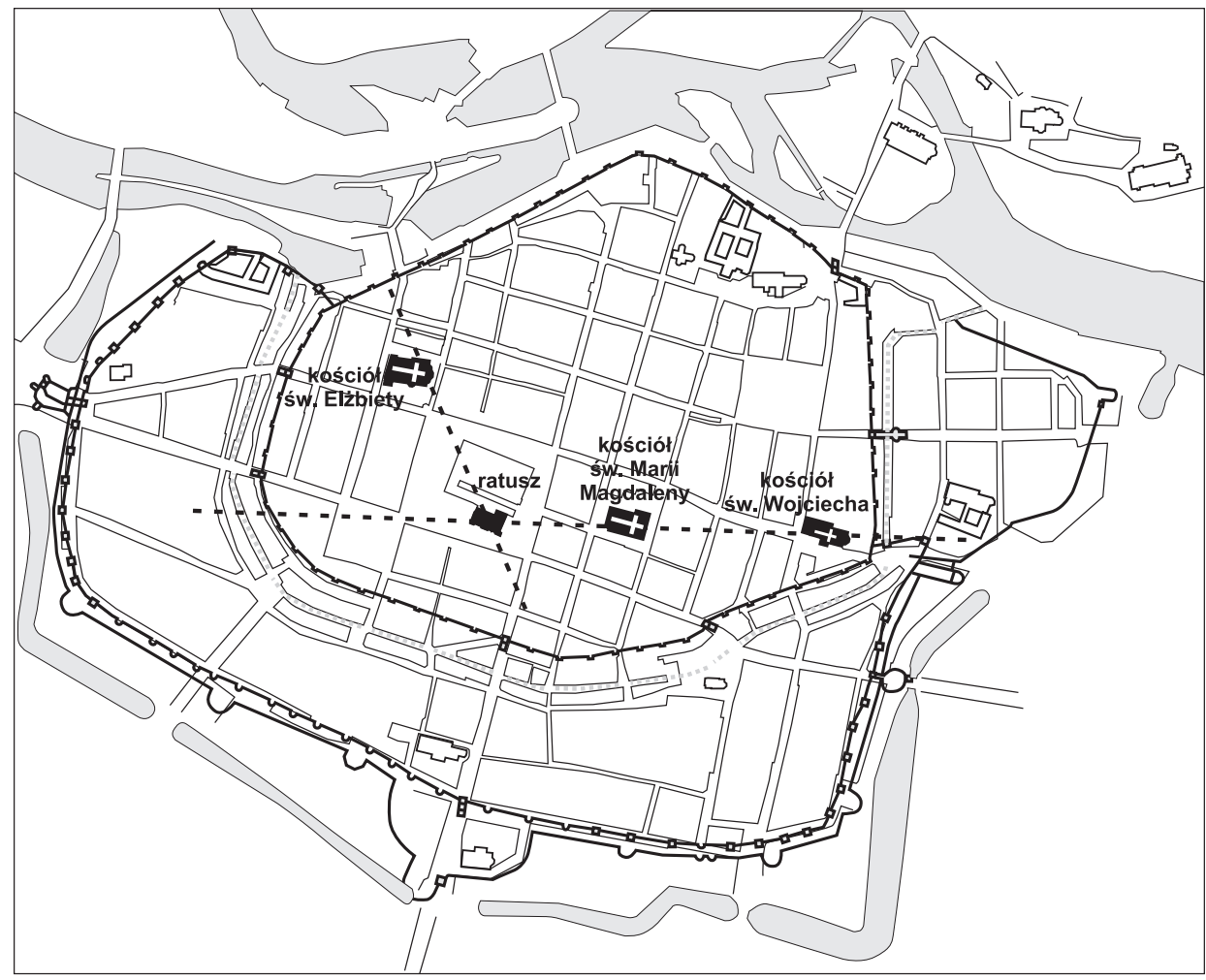

Il. 10. Wrocław wg planu Fryderyka Grossa, z około 1560 r.; pierwsza diagonala łączy ratusz i kościół św. Elżbiety. Druga linia łączy od prawej prezbiterium kościoła św. Wojciecha, kościół św. Marii Magdaleny i ratusz; oprac. graf. M. Siehankiewicz 